\title{
EU funds as a catalyst of change for the Slovak health- care system?
}

\author{
Jan Fidrmuc ${ }^{1}$, Kristína Gardoňová ${ }^{2}$, Martin Hulényi ${ }^{3}$, Lukáš Sekelský ${ }^{4}$, \\ Veronika Zlaczká \\ ${ }^{1}$ Université de Lille, Lille, France; PRIGO University, Havírov, Czech Republic; CESifo, Munich, \\ Germany \\ ${ }^{2}$ Institute for Strategy and Analysis (ISA), Government Office of the Slovak Republic, Bratislava, \\ Slovakia \\ ${ }^{3}$ Université de Lille, Lille, France \\ ${ }^{4}$ Ministry of Health of the Slovak Republic, Bratislava, Slovakia
}

Received: 29 November 2020/Accepted: 26 November 2021

\begin{abstract}
In the programming period 2007-2013, the European Structural and Investment Funds $($ ESIF) invested $€ 237$ million in Slovak hospitals. We investigate whether this injection of additional funds has improved the quality of healthcare in the targeted hospitals. As a measure of healthcare quality, we use the readmission rate (ratio of readmissions within 30 days over total hospitalizations) and the mortality rate. Our results show a statistically significant but small effect of ESIF on the readmission rate but not on the mortality rate. We argue that these results suggest that the main problem in Slovak healthcare is low productivity rather than a lack of funding.
\end{abstract}

JEL classification: H51, H87, I18, F36

Key words: healthcare, public finance, productivity, difference in differences

\section{Introduction}

The quality of healthcare provision in Slovakia is underwhelming. Despite Slovakia undergoing a substantial degree of development since its accession to the EU, its healthcare system continues to lag behind those of other EU Member States. This can be seen especially in terms of its relatively high amenable mortality rate, which is among the highest in the EU. Furthermore, Slovakia lags behind other EU countries in preventative healthcare and in the quality of primary care provision, which, in turn, leads to unnecessarily frequent admissions to hospital (OECD, European Observatory on Health Systems Policies 2017).

In this paper, we seek to identify the causes for the underperformance of the Slovak healthcare system. The basic premise motivating this analysis is that poor performance of healthcare could be attributable to one of the following two reasons. First, the healthcare system could be underfunded. If this is the case, some patients may not receive the required treatment because of a lack of funds. They may instead receive treatment that is cheaper but less effective than the best-possible course of action, or the healthcare providers lack the necessary equipment to diagnose and treat patients appropriately. 
Second, the resources within the healthcare system could be used inefficiently. For example, healthcare providers may be allocating a significant share of available funds to relatively unproductive aspects of their work. This could include filling out forms and reporting, instead of looking after patients. Expensive equipment may also be allocated to hospitals that do not need it while hospitals that could better utilize them remain without. The remedy aimed at improving the quality of healthcare should address the cause of its deficiency. If the healthcare system is underfunded, then injecting additional funds would be productive. In contrast, inefficient use of existing resources will not be improved by giving the hospitals additional funds; instead, the underlying causes of inefficiency should be identified.

We model the provision of healthcare as a production process transforming measurable inputs into measurable outcomes. Thus, we estimate a production function to observe the effect of injecting additional funds on hospital-specific readmission and mortality rates. During the 2007-2013 programming period, around $€ 265$ million from the European Structural and Investment Funds (henceforth ESIF or EU Funds) were invested in Slovak healthcare facilities, of which the vast majority ( $€ 237$ million) went to hospitals ${ }^{1}$. We investigate the impact of the overall amount of ESIF spent, and the impact of spending according to the different categories of ESIF (infrastructure, equipment, and personnel and other expenses).

Our results reveal a small but statistically significant favorable effect of the ESIF on the readmission rate one year after the allocation of the funds. In contrast, we find no effect on the overall mortality rate. When we divide the EU funds according to the expenditure categories, we find that only investments into construction and reconstruction of hospitals have had a statistically significant effect on the readmission rate. Furthermore, while the ESIF seem to affect some sub-categories of mortality, the results are mixed - we find both positive and negative effects. Moreover, even when the results are statistically significant, they are very small in magnitude.

The small magnitude of the estimated effects suggests that the Slovak healthcare system is on the predominantly flat segment of the production function, where injections of additional funds are associated only with limited improvements in the quality of outputs. Therefore, the unfavorable performance of the Slovak healthcare system does not seem to be primarily due to underfunding. Rather, the problem is inefficient use of the available funds: what is needed is an improvement that would shift the production function upwards.

\section{Conceptual Framework}

A popular way of evaluating the impact of spending on healthcare quality is by means of a production function, which relates the amount of spending on healthcare (inputs) to the health of the inhabitants of an economy (output). The main input factor is typically the expenditure on healthcare. To control for specific conditions and other inputs, socioeconomic, lifestyle and environmental factors can also be used in the model. Outcomes are usually measured in terms of life expectancy, hospital readmissions, or mortality. Life expectancy can be either estimated at birth or at a higher age (such as $65+$ life expectancy, life expectancy adjusted for quality of life, or considering only healthy life expectancy). Life expectancy measures are the most comprehensive indicators of health and quality of life, reflecting the combined effect of healthy lifestyles, nutrition, healthcare and other factors, over long periods (Thornton 2002, Lubitz et al. 2003, Nixon, Ulmann 2006, Gallet, Doucouliagos 2016). As such, they are well suited for analyses of longterm trends or comparative multi-country analyses. On the other hand, short-lasting interventions are unlikely to be reflected in changes in life expectancy. Therefore, to analyze short-term aspects of healthcare provision, hospital readmission and mortality rates may be more suited. Hospital readmissions, typically measured as readmission of

\footnotetext{
${ }^{1}$ Although the 2007-2013 Programming period ended in 2013, EU Member States had the possibility to draw on funds allocated within this period until 2015 under the so-called "n+2 rule", with Romania and Slovakia gaining an extension to $n+3$, to mitigate the possible risk of losing funds. See http://europa.eu/rapid/press-release_IP-13-446_en.htm.
} 
the same patient with 30 days of having been discharged, are a particularly good measure, as a significant proportion of such readmissions have been found to be avoidable: more than half, according to some studies (Benbassat, Taragin 2000, Van Walraven et al. 2011). Because of this, hospital readmissions were chosen as a criterion of quality of hospital performance under the US Affordable Care Act (McIlvennan et al. 2015, Zuckerman et al. 2016). Finally, mortality - either overall or by specific cause of death - is another valuable indicator of quality of healthcare, which is also suited for analyses of short-term trends and variations (Or 2001, Nolte, Mckee 2004, Prentice, Pizer 2007). A potential downside is that it can be subject to endogeneity and measurement/reporting issues (Dreger, Reimers 2005). For example, a poorly run healthcare system may result in a large share of the elderly dying in their homes rather than in hospitals, with their passing attributed to old age rather than to the true cause of death. Inasmuch as healthcare improvements lead to an increase in hospital admissions of the elderly, such improvements can actually translate into an increase in reported mortality in hospitals and/or mortality due to specific ailments.

In their meta-analysis of production function-based models, Gallet, Doucouliagos (2016) show that healthcare spending has a greater impact on mortality than on life expectancy: the elasticities of spending with respect to mortality rate and life expectancy are around -0.13 and 0.04 respectively. Gallet, Doucouliagos (2016) note that these relatively low elasticities may be due to other factors (income, demographics and lifestyle choices) playing significant roles. Similarly, Nixon, Ulmann (2006), looking at the 15 Member States of the European Union in 1980-1995, find that increases in healthcare expenditure are significantly associated with lower child mortality, but only with modest improvements in life expectancy. At the same time, however, they note that these relatively low elasticities may signify an importance of other factors (income, demographics and lifestyle choices). Martin et al. (2008) looked at spending on two special care programs, cancer patients and patients with cardiovascular diseases, with the latter having a higher elasticity of spending with respect to disease related deaths. Thornton (2002) also points out that the additional spending on medical care is relatively ineffective in reducing patient mortality and prolonging life expectancy; with the most important factors affecting mortality rates being socio-economic status and lifestyle. They also suggest that the effect of healthcare spending may have diminishing returns.

A number of analyses aim to define, measure and improve the organizational efficiency of healthcare facilities around the world. Palmer, Torgenson (1999) define three main aspects of efficiency in healthcare facilities: technical, allocative and productive efficiency. Technical efficiency refers to the use of given inputs in the most efficient way, given the currently available technology. A production process is technically efficient if reducing the amount of any input would lead to a reduction in output. Productive efficiency, in turn, refers to achieving a given outcome with the lowest possible cost. For example, if the same outcome could be achieved with two or more different combinations of inputs, the least costly input combination is productively efficient. Allocative efficiency, finally, reflects the ability to allocate its resources in a manner that maximizes social welfare.

The generally low estimated elasticities of healthcare spending suggest that the production of healthcare may be inefficient: the available resources and technologies are not used optimally, so that the same outputs could be produced with lower cost. Injections of additional funds have the potential to improve all three aspects of efficiency. New healthcare infrastructure and equipment can improve the quality of healthcare, new skills and techniques acquired through additional training help improve the utilization of available resources, and improvements in the provision of healthcare can help remove disparities in the quality of healthcare received by different individuals.

The previous literature assessing the impact of EU funds on healthcare in Slovakia relies primarily on descriptive analyses. The evaluation of the impact of EU funds on healthcare by KPMG (2013) concludes that the EU funds from Operational Programme Health (OPH) improved the healthcare in Slovakia by $58 \%$ in terms of quality, $24 \%$ in terms of efficiency, and $18 \%$ in terms of availability. The authors had to deal with several limitations. First, the OPH does not define criteria for quality, availability or efficiency. For that reason, the authors themselves had to define these terms and the causal links 


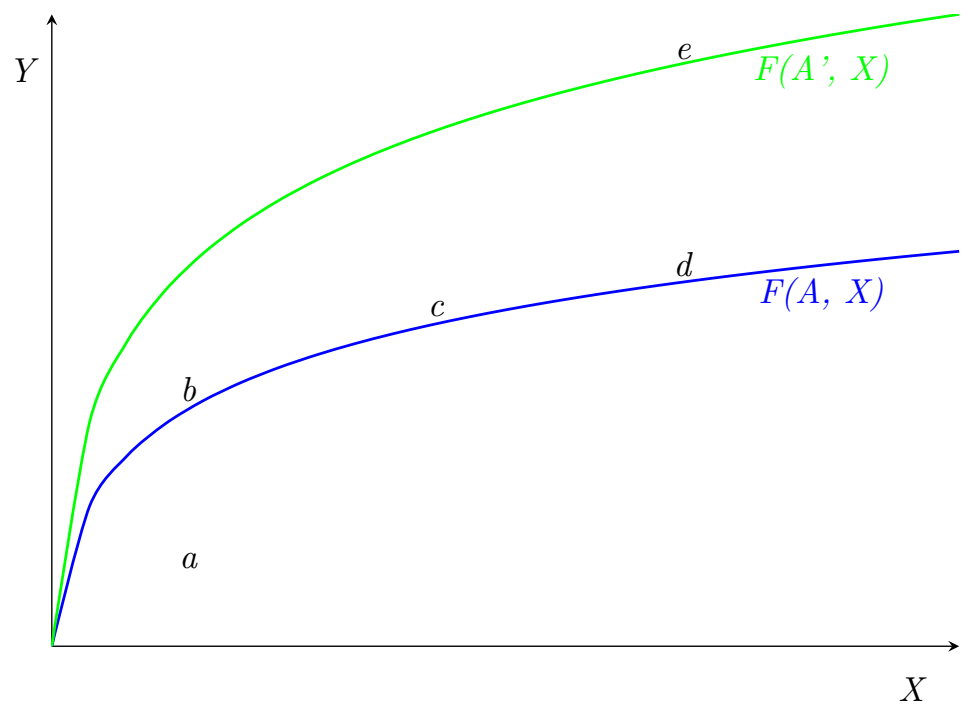

Notes: The graph depicts output, $Y$, as a function of a factor of production, $X$, and technology (efficiency) A. An increase in inputs corresponds to moving to the right along the horizontal axis. An improvement in technology is associated with a vertical shift of the production function profile. Points $a$ through $d$ thus correspond to outcomes with different inputs but the same technology (efficiency), while point $e$ is on a production function associated with more advanced technology (higher efficiency).

Figure 1: Production function and injection of additional funds

between them. This was undertaken through a structured approach of identifying the relationship and contribution of projects and their outputs to the quality, effectiveness, and availability of healthcare. It is, however, questionable whether descriptive analysis is a suitable method for finding causal linkages.

Furthermore, there is also a lack of quantitative assessments of the effect of ESIF on healthcare in other EU countries. Murauskiene, Karanikolos (2017) use a simple comparison of targeted indicators before and after the 2007-2013 programming period in Lithuania, such as the number of beds or life expectancy. A more common approach is to evaluate case studies: for instance, Pasowicz et al. (2009) look at the role of ESIF in the modernization of John Paul II Hospital in Krakow, while Glinos, Baeten (2014) mention the function of ESIF in their case studies of cross border hospital cooperation in the EU.

Our study aims to address this dearth of quantitative assessments of the impact of spending on healthcare. We follow the rest of the literature by adopting the productionfunction approach: we relate the outputs of healthcare establishments to the available inputs (equipment, labor, and financial resources). The health outcomes we consider are the rate of readmission within 30 days, and the mortality rate (both overall and by different causes of death). We depict our conceptual framework in a stylized form in Figure 1, wherein the graph shows the production function transforming healthcare inputs, $X$, into an output (health), $Y$, using available technology, $A$. The magnitude of the impact that the injection of funds achieves thus depends on where the healthcare system is situated relative to the production function. Consider points $a$ through $e$; points $a$ and $b$ are both associated with the same (relatively low) level of inputs, while $a$ is well below the production function, suggesting that the available resources are spent inefficiently. An injection of additional resources that moves the economy from point $b$ to $c$ is associated with a significant improvement in the level of output. The additional funds help move the healthcare system from the upward sloping segment of the production function (an indication that the healthcare system may be underfunded), to a flatter segment. In contrast, a similar injection of funds moving the healthcare system from $c$ to $d$ only leads to a modest increase in output. At $c$, the healthcare system is not particularly deprived of resources and is already on the flat segment of the production function. A more substantial increase in output can be achieved only by a productivity improvement, 
signified by an upward shift in the production function. This would occur if the injection of additional funds is associated with the adoption of a more efficient technology $\left(A^{\prime}\right.$ instead of $A$ ). The healthcare system can thus move from $c$ to $e$ instead of $d$. Indeed, adopting a more efficient technology alone could lead to a significant increase in output: movement from $d$ to $e$, even without additional resources (although the resource injection may prove a catalyst of an improvement in productivity).

In line with the preceding discussion, we hypothesize that finding evidence of small returns to spending increases would indicate that the healthcare system is on the relatively flat part of the production function. As such, it would not appear substantially underfunded. In contrast, finding large increases in the quality of healthcare outputs would be ambiguous. It could either imply that the healthcare system was on the upward sloping part of the production function (that is, that it was originally underfunded), or that the spending increase translated into a significant productivity improvement. In the latter case, further analysis would be required to identify which of these two cases applies to Slovak healthcare.

\section{Overview of the Slovak Healthcare System}

The Slovak healthcare system ${ }^{2}$ is based on statutory health insurance, which guarantees the same basic benefit package for all insured individuals. The insurance works by means of selective contracting between health insurance companies and healthcare providers. Health insurance companies are obliged to ensure adequate healthcare for their insurant, and compete on both quality and prices. There are three health insurance companies, one public and two private. The Ministry of Health mandates the basic benefit package and maximum waiting lists, and ensures that the health insurance companies contract sufficient numbers of healthcare providers.

Healthcare services can be distinguished as either ambulatory (outpatient) care, or inpatient and other healthcare. Ambulatory care provides care to patients not admitted to the healthcare institutions. Inpatient care includes all types of hospitals, professional medical institutions and specialized sanatoriums, palliative care, spas and health resorts. Other care includes emergency medical services, home nursing care and dialysis centers. Thus, a broad range of establishments are involved in providing healthcare services, from general practitioners, through narrowly-focused clinics to hospitals with a large number of diverse wards.

When comparing Slovakia to neighboring countries or the EU as a whole, the Slovak healthcare sector appears to underperform on a number of criteria. The Ministry of Health of the Slovak Republic (2007) notes that healthcare infrastructure is often outdated. For instance, medical equipment had an average age of 10 years, in some regions even 12 years. As a result, Slovakia lags behind the other EU countries in terms of the health status of its population. According to Medeiros, Schwierz (2015), if Slovakia were to reduce its inefficiencies in healthcare, life expectancy could be 6.4 years higher at birth and 3.2 years higher at age 64 . Hence, EU Funds have the potential to improve the quality of healthcare and increase the effectiveness.

Overall, $€ 237$ million were invested in Slovak hospitals during the 2007-2013 programming period, $95 \%$ of which was disbursed under Operational Programme Health (OPH). The stated objectives of OPH included, according to the Ministry of Health of the Slovak Republic (2007), improving the quality, accessibility and effectiveness of healthcare and health support, and to reduce the relatively high morbidity and mortality rates due to circulatory system diseases, carcinomas, respiratory system diseases, digestive system diseases and external causes. It aims to achieve this by investing into healthcare infrastructure (construction of new capacities, reconstruction of buildings, delivery of medical equipment and IT equipment).

Allocated EU funds have to be accompanied by matching spending from domestic sources (private, public, or a combination of the two $)^{3}$. The co-financing share was

\footnotetext{
${ }^{2}$ For further details about Slovak healthcare, see Kuenzel, Solanič (2018).

${ }^{3}$ Specific rules on the co-financing rate depend on the specific fund of the EU budget, from which the finances stem. For details consult Council Regulation (EC) No. 1083/2006 of 11 July 2006 available at
} 
between $15 \%$ and $19.25 \%$ of the projected amount, depending on the ownership structure (Ministry of Health of the Slovak Republic 2007). For privately held hospitals, the EU contribution was $80.75 \%$, with $14.25 \%$ contributed from national public sources and the remaining $5 \%$ by the hospital itself. In the case of publicly owned hospitals, the EU contribution was $85 \%$, with $15 \%$ coming from governments at the federal and local levels.

\section{Data and methodology}

Our goal is to investigate the impact of the ESIF on the performance of hospitals in Slovakia. To observe the impact of the ESIF, we have obtained a detailed list of all ESIF-financed projects in Slovakia during the 2007-2013 programming period. The data were provided by the Central Coordination Body, a department at the Deputy Prime Minister's Office ${ }^{4}$ responsible for the oordination of the ESIF in Slovakia, who extracted this information from the central information systems of EU funds (ITMS). For the purposes of our analysis, we define a hospital as a healthcare facility that contains at least the following departments: internal medicine, surgical department, central admissions office, and department of anesthesia and intensive medicine. In this way, we exclude small and narrowly focused establishments such as dermatology clinics, cosmetic surgery clinics, or centers treating addiction. Based on these criteria, we identify 67 hospitals in Slovakia.

We used the hospitals' identification numbers to match EU funds received with each individual hospital. However, we encountered some cases in which several hospitals had the same identification number; this was due to some of them having the same owner. This problem was solved by contacting the managerial authorities responsible for the operational programs and asking them about the recipient of the funds. Furthermore, one project involved two separate hospitals. In this case, we divided the total amounts based on the number of doctors working in each hospital ${ }^{5}$.

Overall, 30 of the 67 hospitals received EU funds during the 2007-2013 programming period. Figure 2 presents the number of hospitals that have drawn ESIF in each year as well as the amount that was disbursed in each year ${ }^{6}$. The absorption of funds by Slovak hospitals was quite low at the beginning of the 2007-2013 programming period, with peak spending occurring in $2012^{7}$.

Figure 3 presents the regional distribution of the ESIF. Hospitals in Prešov, Banská Bystrica, and Košice regions received the greatest funding levels. On the other hand, no funds were allocated to hospitals in the Bratislava region. This is due to its status as a more developed region, meaning its GDP per capita exceeds $90 \%$ of the EU average ${ }^{8}$. Therefore, the Bratislava region was eligible for support only under the regional competitiveness and employment objectives, making it more difficult to invest ESIF in hospitals in this region.

Figure 3 also depicts the regional distribution of ESIF by categories of expenditure. Notice that the bulk of ESIF were spent on infrastructure (construction and reconstruction work) and medical equipment. Only in two regions, Trnava and Trenčín, were more ESIF invested in medical equipment than in infrastructure ${ }^{9}$. Investments in personnel,

https://eur-lex.europa.eu/legal-content/EN/ALL/?uri=CELEX:32006R1083. In this paper we summed all sources of finance together.

${ }^{4}$ From 1 July 2020, the Deputy Prime Minister's Office has been transformed to Ministry of Investments, Regional Development and Informatisation of the Slovak Republic.

${ }^{5}$ The project "Further education of hospital staff", No. 27140130038, financed educational and training sessions in hospitals in Žiar nad Hronom and Rimavská Sobota.

${ }^{6} \mathrm{~A}$ hospital applying for ESIF at first finances the expenditure by themselves, and submits a request for reimbursement that is then assessed by the managing authority. In Figure 4 as well as throughout the whole paper we allocate the funds to the year in which the beneficiary paid the contractor.

${ }^{7}$ Recall that EU allowed Member States to draw unspent funds allocated in the 2007-2013 budget also during the 2-3 years immediately following the end of the programming period (see footnote 1).

${ }^{8}$ The EU classifies regions into less developed (with GDP per capita up to $75 \%$ of the EU average), transition regions (75 to $90 \%$ ) and more developed regions (GDP per capita exceeding more than $90 \%$ of the EU average).

${ }^{9}$ This reflects a government assessment of the needs of the individual regions, which found that Trnava and Trenčín were especially in need of new medical equipment (see Ministry of Health of the Slovak Republic 2007). 


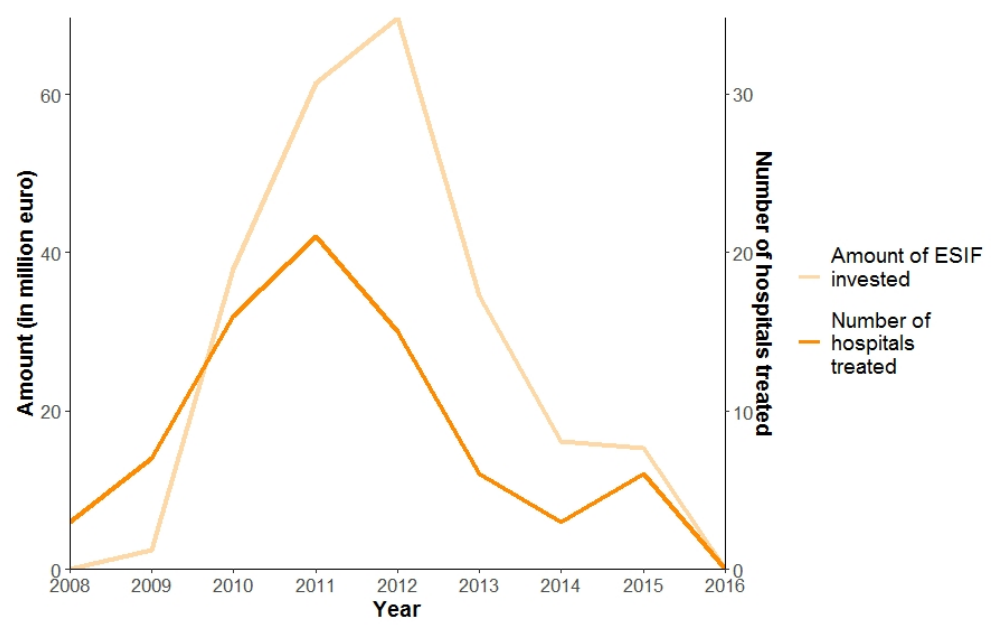

Data source: ITMS.

Figure 2: Development of absorption of ESIF in hospitals

comprising spending on wages and training, and other expenditures, were comparatively small. As the distribution by categories suggests, the highest amount, $€ 225$ million or $95 \%$ of the whole allocation, was drawn from the OPH. The main objective of this operational programme was to improve the quality of healthcare through construction and reconstruction of healthcare infrastructure.

As the majority of the ESIF were spent on modernizing hospital infrastructure (construction or reconstruction), the impact on readmission rates is not entirely straightforward. Staying in a newly built or refurbished building might increase the enjoyability of one's stay in a hospital, but the improved infrastructure should only have a limited impact on the quality of the treatment provided. However, infrastructure improvements also serve to decrease a hospital's running costs, and such savings can be used to improve the quality of healthcare. Furthermore, in as much as the improvements were necessary to maintain the functionality of a hospital, obtaining external financing reduces the need to finance such planned expenditure from a hospital's own budget. Thus, funds freed up in this way can be redirected to other uses where they can have a direct impact on the readmission or mortality rates ${ }^{10}$.

Although many previous studies used life expectancy as the outcome variable, as we discuss above, life expectancy can be attributed to numerous other factors besides the quality of healthcare system or the expenditure on it. It is also a long-term measure, and as such it would be ill-suited for an analysis of the impact of a relatively shortlasting intervention. Instead, we use the readmission rate, which we define as the rate of readmissions within 30 days of the original hospitalization, and the mortality rate, including its subcategories.

Data on readmission and mortality rates in Slovak hospitals during 2010-2017 cover the healthcare treatments recorded by Všeobecná zdravotná poisťovňa (VšZP, the public health insurance company) and were provided to us by the Ministry of Health of the Slovak Republic. VšZP is the oldest and largest health insurance provider, with a market share of $57.73 \%$ as of 1.1 .2020 (this share was even higher during the years covered by the analysis ${ }^{11}$. The data show insurance claims by clients of the VšZP at the level

\footnotetext{
${ }^{10}$ Such spillover effects are similar to the crowding out of investment by development aid. The literature studying the effect of aid on investment in less developed countries routinely finds that receiving aid for investment projects leads to a reduction in investment by the recipient country and an increase in government consumption. In other words, the aid received allows the recipient country to free up some of its own resources originally earmarked for investment and redirect them to other uses (see Section 5 in Doucouliagos, Paldam 2009). It is reasonable to expect a similar pattern at the level of hospitals.

${ }^{11}$ Since 2013 around 200,000 switched to one of the two private insurance companies. For more information see: https://www.vszp.sk/showdoc.do?docid=2219\&forceBrowserDetector=blind and http://www.udzs-sk.sk/documents/14214/29608/OZNAMENIE_podiel+PP_web_1.1.2020.pdf/d1b1004834f5-4a0a-ba72-83c85c51bd30.
} 


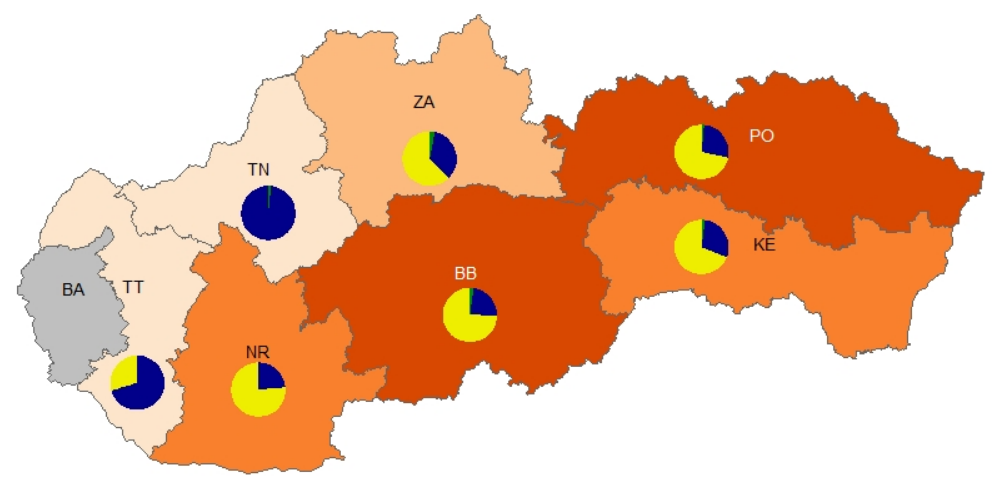

Sum of ESIF invested in hospitals (in millions)

3.5 to $25.2 \quad 25.2$ to $32.6 \quad 32.6$ to $47.7 \quad 47.7$ to 55.5 No funds drawn

Construction $\square$ Equipment $\square$ Other

Data source: ITMS.

Note: Hospitals in Bratislava region were not eligible for EU funds. The abbreviations in Figure 3 represent the names of the regions: Bratislava region (BA), Trnava region (TT), Trenčín region (TN), Nitra region (NR), Žilina region (ZA), Prešov region (PO) and Košice region (KE).

Figure 3: ESIF invested in hospitals (in millions of Euros) and breakdown by type of expenditure

of hospital departments; these were added up to compute the hospital-level aggregates. However, the data on readmission rates are incomplete for 17 hospitals. We imputed the missing observations by bootstrapping from the existing data using the hospitals trends.

We have also included various additional control variables to ensure the model is well specified and free of omitted variable bias by accounting for the possible impact of hospital specific factors on the readmission and mortality rates. Quality of healthcare might be affected by the nature of ownership of the healthcare facility (Czypionka et al. 2014, Berger, Messer 2002) and the number of medical devices available at the hospital (Retzlaff Roberts et al. 2004, Samut, Cafri 2016, Stefko et al. 2018). Hospitals with an oncology department or an intensive care unit tend to deal with more serious cases so they are likely to have higher readmission and mortality rates. Similarly, the capacity and occupancy of the hospital might influence the readmission rate. Furthermore, we also control for the effects of several socio-economic variables at the district level: the average wage, perinatal mortality, economic dependency ratio (number of people in retirement age divided by the number of people of working age), population density, and the share of people of the Roma ethnicity (who tend to suffer from significant economic and social exclusion) in the district's population. We obtained these data from the Statistical Office of the Slovak Republic ${ }^{12}$.

In order to estimate the impact of ESIF investments on the quality of healthcare, we estimate the production function of healthcare quality for hospital $i$ located in district $j$ in time period $t$ :

$$
\ln Y_{i t}=\beta_{0}+\beta_{1} \ln \text { ESIF }_{i t}+\gamma \text { hos_controls }_{i t}+\delta \text { socecon_controls }_{j t}+\tau_{t}+\mu_{i}+u_{i t}
$$

ESIF denotes the cumulative sum of all ESIF invested by period $t$ in a given hospital: adding-up the EU funds in this way allows us to evaluate their long-term effect. The reason is that the expenditure should not only impact the quality of healthcare in the same year but also in the following years ${ }^{13}$. Furthermore, hosp_controls and soc-

\footnotetext{
${ }^{12}$ In the discussion of our findings below, we focus on the ESIF effect. The full regression results for all control variables can be found in the Appendix.

${ }^{13}$ The alternative would have been to consider different lag length to see which yields the best results. However, as we explain above, we are precluded from doing this by the changes in how the data were collected in 2016 and subsequent years.
} 


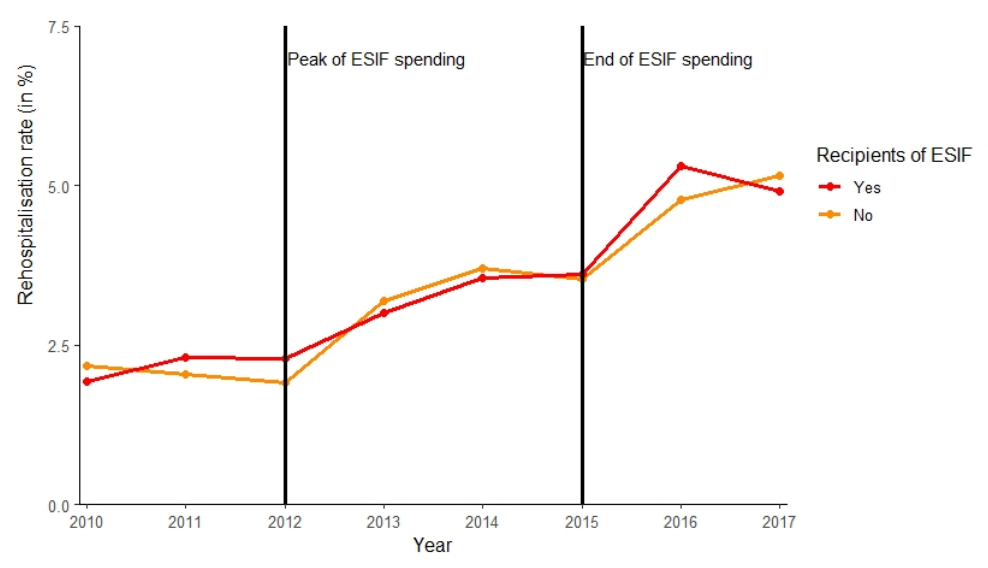

Data source: National health information center.

Figure 4: Development of the readmission rate in Slovak hospitals in 2010-2017

econ_controls represent the hospital and district controls, respectively ${ }^{14}$. Lastly, $\tau_{t}$ denotes the time fixed effects and $\mu_{i}$ stands for the individual fixed effects.

As we are also interested in the impact of different categories of ESIF, we also estimate the following model:

$$
\begin{aligned}
\ln Y_{i t}= & \beta_{0}+\beta_{1} \ln \text { constr }_{i t}+\beta_{2} \ln \text { equip }_{i t}+\beta_{1} \ln \text { persother }_{i t}+ \\
& \quad \gamma \text { hos_controls }_{i t}+\delta \text { socecon_controls }_{j t}+\tau_{t}+\mu_{i}+u_{i t}
\end{aligned}
$$

where constr, equip and persother represent the ESIF invested in infrastructure, equipment, and other expenses (which also includes personnel expenses that are too small to be used as a separate category), all expressed as cumulative sums.

We adjust the data in a number of ways. First, although the hospitals were also receiving EU funds in 2008 and 2009, due to limited availability of data on the quality of healthcare in hospitals in these years we cannot include them in our model. However, not considering the funds utilized by hospitals in 2008 and 2009 should not affect our results much because, as Figure 2 shows, the drawing rate of ESIF in these two years was negligible. Second, we exclude the years 2016 and 2017 from our model, because in these two years the ESIF from the programming period 2007-2013 were no longer drawn. As can be seen in Figure 4, the readmission rate increased in 2016 and 2017. This increase is not caused by changes in Slovak healthcare, but rather by an improvement in data collection. Hence, the inclusion of these two years might distort the results. Due to missing data on the hospital controls we have an unbalanced panel ${ }^{15}$. Lastly, we take logarithms of variables, with the exception of binary variables, and added 1 to the variables expressed as ratios before taking logarithms of them to prevent additional loss of data as they contained numerous zeros.

We estimate models with contemporaneous cumulative ESIF and with its first lag. All in all, our two models cover 67 hospitals, of which 30 were drawing ESIF over the period 2010-2015.

In Table 1, we present the descriptive statistics for both groups of hospitals, that is, hospitals that were recipients of funds, and those that did not receive any funds during our observation period. The two groups of hospitals are similar, but some important differences stand out. The hospitals that drew EU funds have a higher capacity in terms of beds as well as more medical personnel and specialized medical

\footnotetext{
${ }^{14}$ Some of the control variables at the hospital level (new patients, capacity of the hospital and the number of medical devices) were divided by the number of medical personnel to control for the size of the hospital.

${ }^{15}$ Out of the 67 hospitals in our dataset we are missing complete times series for several variables in the case of seven hospitals, with two of them belonging to the treatment group. For approximately ten others we have incomplete time series.
} 
Table 1: Comparison of mean values of variables between ESIF recipients and other hospitals

\begin{tabular}{lcccccc}
\hline & & 2010 & & & 2015 \\
ESIF recipients & Yes & No & Difference & Yes & No & Difference \\
\hline Number of hospitals & 17 & 50 & -33 & 30 & 37 & -7 \\
ESIF [euros] & $1,346,473.15$ & 0.00 & $1,346,473.15$ & $7,913,732.23$ & 0.00 & $7,913,732.23$ \\
Readmission rate1 & $1.83 \%$ & $2.15 \%$ & -0.32 p.p. & $3.50 \%$ & $3.41 \%$ & 0.10 p.p. \\
Mortality rate2 & $2.06 \%$ & $2.53 \%$ & $-0.48 \mathrm{p} . \mathrm{p}$. & $2.07 \%$ & $2.27 \%$ & -0.21 p.p. \\
Capacity3 & 493.52 & 368.80 & 124.72 & 452.75 & 327.86 & 124.89 \\
Occupancy4 & $66.99 \%$ & $61.83 \%$ & 5.16 p.p. & $67.46 \%$ & $64.87 \%$ & 2.59 p.p. \\
Intensive Care [0/1] & 0.53 & 0.49 & 0.05 & 0.67 & 0.59 & 0.07 \\
Oncology [0/1] & 0.10 & 0.03 & 0.07 & 0.03 & 0.03 & 0.01 \\
CT5 & 1.13 & 0.73 & 0.40 & 1.17 & 0.91 & 0.26 \\
MR5 & 0.52 & 0.15 & 0.37 & 0.38 & 0.15 & 0.23 \\
Perinatal mortality6 & 5.87 & 5.54 & 0.33 & 5.96 & 5.15 & 0.82 \\
Average wage7 & 730.50 & 814.84 & -84.34 & 884.07 & 956.62 & -72.55 \\
Population density8 & 205.49 & 514.93 & -309.45 & 201.83 & 505.92 & -304.09 \\
Old age dependency9 & 17.22 & 18.12 & -0.91 & 20.91 & 21.64 & -0.73 \\
Roma share10 & 2.32 & 2.21 & 0.11 & 2.41 & 1.95 & 0.46 \\
State hospital [0/1] & 0.67 & 0.32 & 0.34 & 0.67 & 0.38 & 0.29 \\
Regional hospital [0/1] & 0.20 & 0.57 & -0.37 & 0.07 & 0.38 & -0.31 \\
\hline
\end{tabular}

Data source: National health information center and Statistical Office of the Slovak Republic.

Notes: Hospital controls: 1 Percentage of patients readmitted within 30 days after being discharged from hospital. 2 Percentage of patients who pass away while in hospital. 3 Capacity in terms of number of patients that can be accommodated. 4 Patients admitted as percentage of capacity. 5 Number of devices in the hospital. District controls: 6 Perinatal mortality in the district the hospital is located in. 7 Average salary in the district the hospital is located in. 8 Persons per square kilometer in the district the hospital is located in. 9 Old persons $(65+)$, as percentage of population in economically active age in the district the hospital is located in. 10 Percentage of Roma ethnicity in the population of the district the hospital is located in.

equipment (MRI scanners and CT scanners). Apart from that, we can see that they are located in poorer regions (in terms of the average wage). The $\mathrm{OPH}$ prioritized hospitals that urgently needed repairs or construction works or were located in regions that had high mortality rates due to cardiovascular, respiratory and oncological diseases (Ministry of Health of the Slovak Republic 2007). Therefore, our model may suffer from endogeneity bias due to omitted variables. Because of the lack of data, we are not able to control for all these characteristics. Nevertheless, if endogeneity is present, it would bias the estimates downwards, given that EU funds were prioritized for poorly performing hospitals. Therefore, our results can be interpreted as the lower bound of the impact of ESIF.

Besides the overall mortality rate, we also have information on the main causes of death. These are summarized in Table 2. Note that, given some hospitals have a limited range of departments, not all causes of death are observed in each hospital.

\section{Results}

Table 3 presents the results with contemporaneous effect of the cumulative EU funds on the rate of readmission of patients within 30 days. Columns (1-2) present the results obtained with hospital fixed effects only, while columns (3-4) also feature time fixed effects. In Columns (1) and (3), we report the regression results obtained with the total ESIF, while the results with subcategories of spending are reported in Columns (2) and (4) ${ }^{16}$. The effect of EU spending overall is insignificant; when looking at subcategories, only ESIF invested into construction and reconstruction of hospitals seem to have a statistically significant negative effect on the readmission rate. Thus, it appears that investing more funds in construction and reconstruction of hospital premises results in a lower rate of patient readmissions. Controlling for time fixed effects makes little difference, which is reassuring. Our results do not capture some unobserved nation-wide

\footnotetext{
${ }^{16}$ In the main body of the paper, we only report the coefficient estimates for the EU Funds. The full results, with all control variables, are available in the Appendix.
} 
Table 2: Descriptive statistics: mortality by cause of death and other indicators

\begin{tabular}{lccccc}
\hline Variable & Obs. & Mean & Std. Dev. & Min & Max \\
\hline Mortality after femur fracture (age over 65) & 283 & 0.11 & 0.08 & 0 & 1 \\
Mortality caused by myocardial infarction after emer- & 292 & 0.07 & 0.09 & 0 & 1 \\
gency (age 35-74) & 320 & 0.14 & 0.10 & 0 & 1 \\
Mortality after acute stroke & 329 & 0.02 & 0.02 & 0 & 0.10 \\
Mortality after interventions & 309 & 0.05 & 0.04 & 0 & 0.25 \\
Mortality in ICUs & 308 & 0.22 & 0.25 & 0 & 2.00 \\
Ratio of transfers to ICUs & 352 & 0.00 & 0.00 & 0 & 0.01 \\
Mortality in regular wards after transfer from ICU & 353 & 0.00 & 0.00 & 0 & 0.08 \\
Pressure ulcer & 308 & 0.22 & 0.25 & 0 & 2.00 \\
Ratio of transfers to ICUs * & 299 & 0.57 & 0.17 & 0 & 1 \\
Operation rate ** & & & &
\end{tabular}

Data source: National health information center.

Notes: * Ratio of patients transferred to an ICU over total number of hospitalizations. ** Ratio of patients undergoing surgery over total number of hospitalizations.

Table 3: Contemporaneous effect of cumulative ESIF on the readmission rate

\begin{tabular}{lcccc}
\hline & $\begin{array}{c}(1) \\
\text { Readmission } \\
\text { rate 30 days }\end{array}$ & $\begin{array}{c}(2) \\
\text { Readmission } \\
\text { rate 30 days }\end{array}$ & $\begin{array}{c}(3) \\
\text { Readmission } \\
\text { rate 30 days }\end{array}$ & $\begin{array}{c}(4) \\
\text { Readmission } \\
\text { rate 30 days }\end{array}$ \\
\hline Constant & $-0.265543^{*}$ & $-0.269996^{*}$ & 0.373888 & 0.329155 \\
& $(0.138624)$ & $(0.136596)$ & $(0.225511)$ & $(0.215518)$ \\
ESIF & 0.000219 & & 0.000092 & \\
Construction & $(0.000437)$ & $-0.001070^{* * *}$ & $(0.000416)$ & $-0.001093^{* * *}$ \\
& & $(0.000291)$ & & $(0.000332)$ \\
Equipment & & $0.00067^{*}$ & & $0.000713^{*}$ \\
Persother & & $(0.000323)$ & & $(0.000367)$ \\
& & 0.000860 & & 0.000585 \\
Hospital controls & & $(0.000636)$ & & $(0.000620)$ \\
Socioeconomic controls & Yes & Yes & Yes & Yes \\
Observations & Yes & Yes & Yes & 333 \\
Individual FEs & 333 & 333 & Yes & Yes \\
Time FEs & Yes & Yes & Yes & Yes \\
R-squared & No & No & 0.3667 & 0.3919 \\
Adjusted R-squared & 0.2675 & 0.2936 & 0.323977 & 0.346663 \\
F statistics & 0.230362 & 0.253093 & $5.33^{* * *}$ & $6.02^{* * *}$ \\
\hline
\end{tabular}

Notes: Robust standard errors in parentheses. Full results in the Appendix. ${ }^{* * *} p<0.01,{ }^{* *} p<0.05$, $* p<0.1$.

policy trends in the organization or financing of healthcare.

In Table 4, we lag the EU funds by one year: this is intended to allow for a delay in the investments bearing fruit. The impact of EU funds now appears stronger and is more precisely estimated. In Column (3), when time fixed effects are taken into account, a one-percent increase in the EU funds reduces the readmission rate in the following year by $0.000775 \%$. If we consider that the average readmission rate was $2.68 \%$ during this period, then this is equivalent to a decline of 0.0021 percentage points. Without including time effects, the impact falls just short of being statistically significant. We obtain a slightly higher coefficient when we divide the EU funds into three categories, among which construction and equipment are the most significant. Interestingly, their estimated effects have the opposite signs. Investment in construction, which is the category with the largest proportion of EU funds, lowers the readmission rate, as expected. The positive coefficient for EU funds invested in equipment can be rationalized as an effect of an increased capacity of the hospital. After installing new and more modern equipment, the hospital may receive additional patients and/or is likely to admit patients with more complicated ailments. Being required to treat more complicated cases may then translate into a higher incidence of readmissions.

We also examine the impact of EU funds on the overall mortality rate as well as the main causes of death (Tables 5-7). In case of the overall mortality rate, the results 
Table 4: Lagged effect of cumulative ESIF on the readmission rate

\begin{tabular}{lcccc}
\hline & $\begin{array}{c}(1) \\
\text { Readmission } \\
\text { rate 30 days }\end{array}$ & $\begin{array}{c}(2) \\
\text { Readmission } \\
\text { rate 30 days }\end{array}$ & $\begin{array}{c}(3) \\
\text { Readmission } \\
\text { rate 30 days }\end{array}$ & $\begin{array}{c}(4) \\
\text { Readmission } \\
\text { rate 30 days }\end{array}$ \\
\hline Constant & -0.785390 & -0.792601 & 1.154970 & 1.178965 \\
& $(0.626623)$ & $(0.629372)$ & $(0.852947)$ & $(0.842379)$ \\
Lag_ESIF & -0.000463 & & $-0.000757^{* * *}$ & \\
& $(0.000287)$ & $-0.000775^{* * *}$ & $(0.000272)$ & $-0.000906^{* * *}$ \\
Lag_construction & & $(0.000192)$ & & $(0.000237)$ \\
& & $0.000652^{* * *}$ & & $0.000740^{* * *}$ \\
Lag_equipment & & $(0.000239)$ & & $(0.000250)$ \\
Lag_persother & & -0.000407 & & $-0.000771^{* *}$ \\
& & $(0.000370)$ & & $(0.000324)$ \\
Hospital controls & Yes & Yes & Yes & Yes \\
Socioeconomic controls & Yes & 279 & 279 & 279 \\
Observations & 279 & Yes & Yes & Yes \\
Individual FEs & Yes & No & Yes & Yes \\
Time FEs & No & 0.3322 & 0.4365 & 0.4497 \\
R-squared & 0.3214 & 0.285952 & 0.392766 & 0.402433 \\
Adjusted R-squared & 0.279996 & $5.45 * * *$ & $16.42 * * *$ & $13.96 * * *$ \\
F statistics & $4.11 * * *$ & & & \\
\hline
\end{tabular}

Notes: Robust standard errors in parentheses. Full results in the Appendix. ${ }^{* * *} p<0.01,{ }^{* *} p<0.05$, $* p<0.1$.

show no statistically significant relationship with the EU funds (Table 5). Looking at the various sub-categories of mortality, we find that the absorption of financial resources in hospitals is positively correlated with mortality after femur fracture in the case of patients over 65 , mortality due to myocardial infarction and mortality after transfers from ICU. Femur fracture is a common injury among the elderly associated with significant morbidity, mortality and disability (Bouchard et al. 1996). The positive effects for these two categories could be explained by the fact that hospitals that underwent improvements are likely to receive additional and more serious cases which, in turn, are more likely to end up with the patient passing away. On the other hand, additional financial resources in hospitals are negatively correlated with mortality in ICUs. The remaining categories appear unaffected by EU funds ${ }^{17}$. The mixed effects of investments financed by the ESIF on the various categories of mortality can explain the lack of significance of EU funds with respect to the overall mortality rate.

\section{Conclusions}

In this paper, we evaluate the impact of injecting additional EU funding into hospitals on the quality of healthcare in Slovakia. Between 2010 and 2015, $€ 237$ million of EU grants were invested in 30 Slovak hospitals, with most of these funds utilized for reconstruction of hospital premises or construction of new buildings. We measure the quality of hospital care by means of the readmission rate, defined as the ratio of readmissions within 30 days over total hospitalizations, and the mortality rate. These are outcomes that are unambiguously important for the patients' wellbeing and quality of life. Slovakia is a particularly well-suited subject for such analysis as the performance of its healthcare system compares rather unfavorably to similar countries in the region and to the EU as a whole. One possible explanation for this is lack of funding, as Slovakia spends a lower share of its GDP on healthcare compared to the EU average. In this paper, we aim to shed light on whether the poor performance of the Slovak healthcare system is indeed

\footnotetext{
${ }^{17}$ When we again split the ESIF by categories (construction, equipment, and personnel/other), we find that mortality after femur fracture is positively correlated with ESIF spending on equipment. Mortality due to myocardial infarction shows a negative correlation with purchases of equipment and a positive (and larger) correlation with spending on personnel and other uses. Mortality after interventions falls with expenditure on construction and equipment but increases with personnel and other spending. Mortality in ICUs is weakly negatively correlated with equipment spending, and, finally, the ratio of transfers to ICUs depends negatively on ESIF in construction. These results are available upon request.
} 
Table 5: Contemporaneous and lagged effects of cumulative ESIF on the mortality rate

\begin{tabular}{|c|c|c|c|c|}
\hline & $\begin{array}{c}\text { (1) } \\
\text { Mortality rate }\end{array}$ & $\begin{array}{c}(2) \\
\text { Mortality rate }\end{array}$ & $\begin{array}{c}(3) \\
\text { Mortality rate }\end{array}$ & $\begin{array}{c}(4) \\
\text { Mortality rate }\end{array}$ \\
\hline Constant & $\begin{array}{l}-0.0164 \\
(0.0263)\end{array}$ & $\begin{array}{l}-0.0167 \\
(0.0262)\end{array}$ & $\begin{array}{c}0.2276 \\
(0.1441)\end{array}$ & $\begin{array}{c}0.2346 \\
(0.1469)\end{array}$ \\
\hline ESIF & $\begin{array}{c}0.0000 \\
(0.0001)\end{array}$ & & & \\
\hline Lag_ESIF & & & $\begin{array}{c}0.0000 \\
(0.0001)\end{array}$ & \\
\hline Construction & & $\begin{array}{l}-0.0000 \\
(0.0001)\end{array}$ & & \\
\hline Equipment & & $\begin{array}{c}0.0000 \\
(0.0001)\end{array}$ & & \\
\hline Persother & & $\begin{array}{c}0.0001 \\
(0.0001)\end{array}$ & & \\
\hline Lag_construction & & & & $\begin{array}{c}0.0000 \\
(0.0001)\end{array}$ \\
\hline Lag_equipment & & & & $\begin{array}{c}0.0000 \\
(0.0001)\end{array}$ \\
\hline Lag-persother & & & & $\begin{array}{l}-0.0001 \\
(0.0001)\end{array}$ \\
\hline Hospital controls & Yes & Yes & Yes & Yes \\
\hline Socioeconomic controls & Yes & Yes & Yes & Yes \\
\hline Observations & 344 & 344 & 289 & 289 \\
\hline Individual FEs & Yes & Yes & Yes & Yes \\
\hline R-squared & 0.0851 & 0.0880 & 0.1352 & 0.1384 \\
\hline Adjusted R-squared & 0.0403 & 0.0376 & 0.0843 & 0.0809 \\
\hline F statistics & $1.93^{* *}$ & 1.51 & $2.39 * * *$ & $2.17^{* *}$ \\
\hline
\end{tabular}

Notes: Robust standard errors in parentheses. ${ }^{* * *} p<0.01,{ }^{* *} p<0.05,{ }^{*} p<0.1$. Regressions with time-fixed effects did not differ significantly from those with individual fixed effects.

caused by the low level of funding, or whether it is a sign of low overall productivity of healthcare facilities.

Our results indicate that the injection of EU funds has led to a significant but small decrease in the readmission rate in the following year. An increase in EU funds by one percent is associated with a decrease in the readmission rate by $0.0007 \%$ in the following year. When looking at the break-down of EU-financed investments by category of spending, we see that the favorable impact is driven primarily by spending on the construction and reconstruction of hospital premises. In contrast, we find that investments in equipment are correlated with slightly higher readmission rates in the next year. We think that this latter result may be caused by hospitals with new equipment receiving more acute patients from other hospitals. The impact of ESIF on mortality rates is statistically insignificant. When we look at the various subcategories of mortality, the results are mixed: we observe some positive but also negative effects, all of which tend to be rather small.

How are we to make sense of the result that injections of EU funds are associated with only small improvements in healthcare outcomes? First, it suggests that the Slovak healthcare system is at present on the relatively flat segment of the production curve. For this reason, increases in inputs lead only to modest gains in performance. In turn, that means that the healthcare system is not at present underfunded, had that been the case, we would expect much larger gains after the hospitals received additional resources. Rather, what the Slovak healthcare system needs is efficiency improvements. Returning to the production-function paradigm, what is needed is an upward shift in the production function, not movement alongside the existing (and low) production function.

The small gains can also be related to the fact that the bulk of EU funds were spent on construction and reconstruction of hospital facilities, that is, on purposes not directly related to provision of healthcare. Such funding can affect the quality of healthcare only indirectly, by freeing up hospitals' own funds to be redirected to other uses. Our findings suggest that such indirect effects are not present or very limited. Nevertheless, it is important to note that several other contributions also find small or zero effects of 
Table 6: Contemporaneous effect of ESIF on the mortality rate in selected categories (part 1)

\begin{tabular}{lcccc}
\hline & $\begin{array}{c}(1) \\
\text { Mortality after } \\
\text { femur fracture } \\
\text { (age over 65) }\end{array}$ & $\begin{array}{c}\text { Mortality caused } \\
\text { by myocardial } \\
\text { infarction after } \\
\text { emergency } \\
\text { (age 35-74) }\end{array}$ & $\begin{array}{c}\text { Mortality after } \\
\text { acute stroke }\end{array}$ & $\begin{array}{c}\text { Mortality after } \\
\text { interventions }\end{array}$ \\
& & & & \\
& & 0.0512 & 2.3563 & 0.0355 \\
Constant & $-1.4762^{*}$ & $(0.8355)$ & $(1.4376)$ & $(0.1353)$ \\
ESIF & $(0.8261)$ & $0.0028^{* *}$ & 0.0015 & -0.0001 \\
Hospital controls & $0.0027^{*}$ & $(0.0012)$ & $(0.0022)$ & $(0.0002)$ \\
Socioeconomic controls & $(0.0014)$ & Yes & Yes & Yes \\
Observations & Yes & Yes & 306 & 319 \\
Individual FEs & 271 & 282 & Yes & Yes \\
R-squared & Yes & Yes & 0.0781 & 0.1212 \\
Adjusted R-squared & 0.1142 & 0.0974 & 0.0271 & 0.0747 \\
F statistics & 0.0585 & 0.0429 & $22.90 * * *$ & $335.94 * * *$ \\
\hline
\end{tabular}

Notes: Robust standard errors in parentheses. ${ }^{* * *} p<0.01,{ }^{* *} p<0.05,{ }^{*} p<0.1$.

Table 7: Contemporaneous effect of ESIF on the mortality rate in selected categories (part 2)

\begin{tabular}{lccccc}
\hline & $\begin{array}{c}(5) \\
\text { Mortality in } \\
\text { ICUs }\end{array}$ & $\begin{array}{c}(6) \\
\text { Ratio of trans- } \\
\text { fers to ICUs }\end{array}$ & $\begin{array}{c}(7) \\
\text { Mortality in } \\
\text { regular wards } \\
\text { after trans- } \\
\text { fer from ICU }\end{array}$ & $\begin{array}{c}(8) \\
\text { Pressure } \\
\text { ulcer }\end{array}$ & $\begin{array}{c}\text { Operation } \\
\text { rate }\end{array}$ \\
\hline Constant & & & -0.0042 & 0.0107 & -0.1128 \\
& 0.3189 & $-5.3445^{*}$ & $(0.0085)$ & $(0.0091)$ & $(2.7022)$ \\
ESIF & $(0.1901)$ & $(2.9647)$ & $0.0000477^{*}$ & 0.0000 & -0.0043 \\
& $-0.0014^{* *}$ & -0.0072 & $(0.0000259)$ & $(0.0000)$ & $(0.0029)$ \\
Hospital controls & $(0.0005)$ & $(0.0044)$ & Yes & Yes & Yes \\
Socioeconomic controls & Yes & Yes & Yes & Yes & Yes \\
Observations & Yes & Yes & 221 & 339 & 291 \\
Individual FEs & 220 & Yes & 0.1405 & 0.0541 & 0.1399 \\
R-squared & Yes & 0.3663 & 0.0776 & 0.0072 & 0.0897 \\
Adjusted R-squared & 0.1465 & 0.3198 & $4.45^{* * *}$ & $1.91^{* *}$ & $5.23^{* * *}$ \\
F statistics & $31.97^{* * *}$ & $41.83^{* * *}$ & Yes & Yes \\
\hline
\end{tabular}

Notes: Robust standard errors in parentheses. ${ }^{* * *} p<0.01,{ }^{* *} p<0.05,{ }^{*} p<0.1$.

spending increases on the quality of healthcare (Or 2001, Nixon, Ulmann 2006, Gallet, Doucouliagos 2016).

Our analysis sheds light on correlation between the EU funds and the quality of healthcare; it does not reflect a causal relationship. Nevertheless, our findings suggest that the unfavorable performance of the Slovak healthcare system (in international comparison) is not due to lack of funding but is attributable to low efficiency. This likely reflects the general lack of qualified healthcare practitioners, both doctors and especially nurses. The lack of qualified staff will worsen over time as a significant proportion of existing doctors and nurses are above 60 years old (ÚHP 2019). Graduates of medical schools tend to migrate to other countries, which will further exacerbate the shortage of medical personnel in Slovakia (Haluš et al. 2017). The low efficiency also reflects a misallocation of resources, with the ratio of general practitioners to specialists at 3 compared to the EU average of 0.6 (ÚHP 2019). If the objective of EU Funds is to generate significant improvements in the quality of healthcare, then future funding programs should focus on fostering knowledge transfer, technology acquisition, and training healthcare professionals rather than (or in addition to) rebuilding facilities. Future research, and the attention of policy makers, should therefore be directed towards identifying potential avenues to improve efficiency and to ensure the healthcare system does not suffer staff shortages. 


\section{Acknowledgement}

This project has been funded by the EU's Operational Programme Technical assistance. We would like to thank Natália Cedzová, Daniel Dujava, Lucia Grajcarová, Gaston Ivanov, Richard Kališ, Daniela Pobudová, Veronika Rybanská, Martin Smatana, Marcela Veselková, Zuzana Zavarská, and participants in the Czech Economic Society and Slovak Economic Association Meeting in Brno in 2019 for their helpful comments. The views expressed in this paper are those of the authors and do not necessarily represent the official position of the Government Office of the Slovak Republic or the Ministry of Health of the Slovak Republic.

\section{References}

Benbassat J, Taragin M (2000) Hospital readmissions as a measure of quality of health care: Advantages and limitations. Archives of internal medicine 160: 1074-1081. CrossRef.

Berger M, Messer J (2002) Public financing of health expenditures, insurance, and health outcomes. Applied Economics 34: 2105-2113. CrossRef.

Bouchard JA, Barei D, Cayer D, O'Neil J (1996) Outcome of femoral shaft fractures in the elderly. Clinical Orthopaedics and Related Research 332: 105-109. CrossRef.

Czypionka T, Kraus M, Mayer S, Rohrling G (2014) Efficiency, ownership, and financing of hospitals: The case of Austria. Health Care Management Science 17: 331-347. CrossRef.

Doucouliagos H, Paldam M (2009) The aid effectiveness literature: The sad results of 40 years of research. Journal of economic surveys 23: 433-461. CrossRef.

Dreger C, Reimers HE (2005) Health care expenditures in OECD countries: A panel unit root and cointegration analysis. Available at SSRN: https://ssrn.com/abstract=651985

Gallet C, Doucouliagos C (2016) The impact of health care spending on health outcomes: A meta-regression analysis. Economic series SWP 2015/11

Glinos IA, Baeten R (2014) Dream vs. reality: Seven case-studies on the desirability and feasibility of cross-border hospital collaboration in Europe. Social Science \& Medicine 117: 18-24

Haluš M, Hlaváč M, Harvan P, Hidas S (2017) Odliv mozgov po slovensky. Institut financnej politiky, Ministerstvo Financii Slovenskej republiky, Available at: https://www.mfsr.sk/sk/media/komentare-ifp-uhp/odliv-mozgov-po-slovensky-januar-2017.html

ÚHP (2019) Healthcare spending review II - Final report. Available at: https://www.mfsr.sk/files/archiv/77/HealthcareSpendingReview2_EN.pdf

KPMG (2013) Hodnotenie dopadov Operačného programu Zdravotníctvo. Záverečná správa. Ministerstvo zdravotníctva Slovenskej republiky

Kuenzel R, Solanič V (2018) Improving the cost-effectiveness of Slovakia's healthcare system. Economic Brief, 041. DG Economic and Financial Affairs, European Commission

Lubitz J, Cai L, Kramarow E, Lentzner H (2003) Health, life expectancy, and health care spending among the elderly. New England Journal of Medicine 349: 1048-1055. CrossRef.

Martin S, Rice N, Smith PC (2008) Does health care spending improve health outcomes? Evidence from English programme budgeting data. Journal of Health Economics 27: 826-842. CrossRef. 
McIlvennan CK, Eapen ZJ, Allen LA (2015) Hospital readmissions reduction program. Circulation 131: 1796-1803. CrossRef.

Medeiros J, Schwierz C (2015) Efficiency estimates of health care systems (No. 549). Directorate General Economic and Financial Affairs (DG ECFIN), European Commission

Ministry of Health of the Slovak Republic (2007) Operational programme health. Available at: http://www.nsrr.sk/download.php?.FNAME=1367841916.upl\&ANA$\mathrm{ME}=$ oph-en-.pdf

Murauskiene L, Karanikolos M (2017) The role of the European structural and investment funds in financing health system in Lithuania: Experience from 2007 to 2013 funding period and implications for the future. Health Policy 121: 727-730. CrossRef.

Nixon J, Ulmann P (2006) The relationship between health care expenditure and health outcomes. European Journal of Health Economics 7: 7-18. CrossRef.

Nolte E, Mckee M (2004) Measuring the health of nations: Analysis of mortality amenable to health care. Journal of Epidemiology \&6 Community Health 58: 326-326

OECD, European Observatory on Health Systems Policies (2017) Slovak Republic: Country health profile 2017. State of Health in the EU, OECD Publishing, Paris, European Observatory on Health Systems and Policies, Brussels. CrossRef.

Or Z (2001) Exploring the effects of health care on mortality across OECD countries. OECD. Labour Market and Social Policy Occasional Paper No. 46, OECD Publishing, Paris. CrossRef.

Palmer S, Torgenson D (1999) Economic notes: Definitions of efficiency. BMJ Clinical Research 318: 1136

Pasowicz M, Latocha-Chaber A, Kautsch M, Durajczyk K, Turek Z (2009) The John Paul II hospital in Krakow, Poland, and the use of European Union grant funds. Capital investment for health case studies from Europe, 41

Prentice JC, Pizer SD (2007) Delayed access to health care and mortality. Health services research 42: 644-662. CrossRef.

Retzlaff Roberts D, Chang CF, Rubin RM (2004) Technical efficiency in the use of health care resources: A comparison of OECD countries. Health policy 69: 55-72. CrossRef.

Samut PK, Cafri R (2016) Analysis of the efficiency determinants of health systems in OECD countries by DEA and panel Tobit. Social Indicators Research 129: 1-20. CrossRef.

Stefko R, Gavurova B, Kocisova K (2018) Health care efficiency assessment using DEA analysis in the Slovak Republic. Health Economics Review 8. CrossRef.

Thornton JA (2002) Estimating a health production function for the US: Some new evidence. Applied Economics 34: 59-62. CrossRef.

Van Walraven C, Bennett C, Jennings A, Austin PC, Forster AJ (2011) Proportion of hospital readmissions deemed avoidable: A systematic review. Canadian Medical Association Journal 183: E391-E402. CrossRef.

Zuckerman RB, Sheingold SH, Orav EJ, Ruhter J, Epstein AM (2016) Readmissions, observation, and the hospital readmissions reduction program. New England Journal of Medicine 374: 1543-1551. CrossRef.

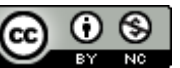

(C) 2022 by the authors. Licensee: REGION - The Journal of ERSA, European

Regional Science Association, Louvain-la-Neuve, Belgium. This article is distri-

buted under the terms and conditions of the Creative Commons Attribution, Non-Commercial (CC BY NC) license (http://creativecommons.org/licenses/by-nc/4.0/). 


\section{A Appendix:}

Table A.1: Contemporaneous effect of cumulative ESIF on the readmission rate - full model

\begin{tabular}{|c|c|c|c|c|}
\hline & $\begin{array}{l}\text { (1) } \\
\text { Readmission } \\
\text { rate } 30 \text { days }\end{array}$ & $\begin{array}{l}\text { (2) } \\
\text { Readmission } \\
\text { rate } 30 \text { days }\end{array}$ & $\begin{array}{l}\text { (3) } \\
\text { Readmission } \\
\text { rate } 30 \text { days }\end{array}$ & $\begin{array}{l}\quad(4) \\
\text { Readmission } \\
\text { rate } 30 \text { days }\end{array}$ \\
\hline Constant & $\begin{array}{c}-0.265543^{*} \\
(0.138624)\end{array}$ & $\begin{array}{r}-0.269996^{*} \\
(0.136596)\end{array}$ & $\begin{array}{c}0.373888 \\
(0.225511)\end{array}$ & $\begin{array}{c}0.329155 \\
(0.215518)\end{array}$ \\
\hline ESIF & $\begin{array}{c}0.000219 \\
(0.000437)\end{array}$ & & $\begin{array}{c}0.000092 \\
(0.000416)\end{array}$ & \\
\hline Construction & & $\begin{array}{c}-0.001070 * * * \\
(0.000291)\end{array}$ & & $\begin{array}{c}-0.001093^{* * *} \\
(0.000332)\end{array}$ \\
\hline Equipment & & $\begin{array}{l}0.000627^{*} \\
(0.000323)\end{array}$ & & $\begin{array}{l}0.000713^{*} \\
(0.000367)\end{array}$ \\
\hline Persother & & $\begin{array}{c}0.000860 \\
(0.000636)\end{array}$ & & $\begin{array}{c}0.000585 \\
(0.000620)\end{array}$ \\
\hline Capacity & $\begin{array}{l}-0.000310 \\
(0.000385)\end{array}$ & $\begin{array}{l}-0.000326 \\
(0.000351)\end{array}$ & $\begin{array}{c}0.000049 \\
(0.000407)\end{array}$ & $\begin{array}{c}0.000017 \\
(0.000372)\end{array}$ \\
\hline Occupancy & $\begin{array}{c}0.042628 \\
(0.035229)\end{array}$ & $\begin{array}{c}0.039042 \\
(0.035018)\end{array}$ & $\begin{array}{c}0.036114 \\
(0.034315)\end{array}$ & $\begin{array}{c}0.030490 \\
(0.034642)\end{array}$ \\
\hline New patients & $\begin{array}{c}-0.014553^{*} \\
(0.007949)\end{array}$ & $\begin{array}{c}-0.014867^{*} \\
(0.007624)\end{array}$ & $\begin{array}{l}-0.009925 \\
(0.007703)\end{array}$ & $\begin{array}{l}-0.010003 \\
(0.007448)\end{array}$ \\
\hline Medical devices & $\begin{array}{c}0.004416 \\
(0.012546)\end{array}$ & $\begin{array}{c}0.007104 \\
(0.012119)\end{array}$ & $\begin{array}{c}-0.000381 \\
(0.011726)\end{array}$ & $\begin{array}{c}0.002303 \\
(0.011287)\end{array}$ \\
\hline $\mathrm{IC}$ & $\begin{array}{c}0.002146 \\
(0.005749)\end{array}$ & $\begin{array}{c}0.003078 \\
(0.005934)\end{array}$ & $\begin{array}{l}-0.002637 \\
(0.005070)\end{array}$ & $\begin{array}{l}-0.001697 \\
(0.005225)\end{array}$ \\
\hline Oncology & $\begin{array}{l}0.014272^{*} \\
(0.007332)\end{array}$ & $\begin{array}{c}0.013181 \\
(0.008856)\end{array}$ & $\begin{array}{c}0.011428^{* *} \\
(0.004535)\end{array}$ & $\begin{array}{l}0.010773^{*} \\
(0.005455)\end{array}$ \\
\hline $\mathrm{CT}$ & $\begin{array}{c}0.000586 \\
(0.002468)\end{array}$ & $\begin{array}{c}0.001850 \\
(0.002517)\end{array}$ & $\begin{array}{c}0.001625 \\
(0.002456)\end{array}$ & $\begin{array}{c}0.002864 \\
(0.002480)\end{array}$ \\
\hline MR & $\begin{array}{l}-0.006358 \\
(0.003985)\end{array}$ & $\begin{array}{r}-0.006880^{*} \\
(0.003935)\end{array}$ & $\begin{array}{c}-0.006177^{* *} \\
(0.002540)\end{array}$ & $\begin{array}{c}-0.006728^{* *} \\
(0.002545)\end{array}$ \\
\hline State hospital & $\begin{array}{c}-0.010493^{* * *} \\
(0.001885)\end{array}$ & $\begin{array}{c}-0.010833^{* * *} \\
(0.001961)\end{array}$ & $\begin{array}{c}-0.016054^{* * *} \\
(0.004352)\end{array}$ & $\begin{array}{c}-0.016175^{* * *} \\
(0.004235)\end{array}$ \\
\hline Regional hospital & $\begin{array}{c}-0.000886 \\
(0.002866)\end{array}$ & $\begin{array}{l}-0.000823 \\
(0.002919)\end{array}$ & $\begin{array}{c}0.003683 \\
(0.003071)\end{array}$ & $\begin{array}{c}0.003296 \\
(0.003208)\end{array}$ \\
\hline Perinatal mortality & $\begin{array}{c}0.001077 \\
(0.001689)\end{array}$ & $\begin{array}{c}0.000593 \\
(0.001648)\end{array}$ & $\begin{array}{c}0.000693 \\
(0.001611)\end{array}$ & $\begin{array}{c}0.000276 \\
(0.001579)\end{array}$ \\
\hline Average wage & $\begin{array}{c}0.018057 \\
(0.021607)\end{array}$ & $\begin{array}{c}0.016919 \\
(0.020930)\end{array}$ & $\begin{array}{l}-0.026035 \\
(0.024024)\end{array}$ & $\begin{array}{l}-0.023398 \\
(0.023672)\end{array}$ \\
\hline Roma share & $\begin{array}{c}0.007260 \\
(0.004546)\end{array}$ & $\begin{array}{c}0.008703^{*} \\
(0.004468)\end{array}$ & $\begin{array}{c}0.003990 \\
(0.004398)\end{array}$ & $\begin{array}{c}0.005766 \\
(0.004298)\end{array}$ \\
\hline Econ dependency & $\begin{array}{c}0.071239 * * \\
(0.031568)\end{array}$ & $\begin{array}{c}0.069779^{* *} \\
(0.029800)\end{array}$ & $\begin{array}{l}-0.006601 \\
(0.025260)\end{array}$ & $\begin{array}{l}-0.005288 \\
(0.023932)\end{array}$ \\
\hline Population density & $\begin{array}{l}-0.000585 \\
(0.020684)\end{array}$ & $\begin{array}{c}0.002908 \\
(0.020219)\end{array}$ & $\begin{array}{c}-0.025804 \\
(0.019709)\end{array}$ & $\begin{array}{l}-0.020925 \\
(0.018752)\end{array}$ \\
\hline Observations & 333 & 333 & 333 & 333 \\
\hline Individual FEs & Yes & Yes & Yes & Yes \\
\hline Time FEs & No & No & Yes & Yes \\
\hline R-squared & 0.2675 & 0.2936 & 0.3667 & 0.3919 \\
\hline Adjusted R-squared & 0.230362 & 0.253093 & 0.323977 & 0.346663 \\
\hline $\mathrm{F}$ statistics & $475.65 * * *$ & $40.68 * * *$ & $5.33 * * *$ & $6.02 * * *$ \\
\hline
\end{tabular}

Notes: Robust standard errors in parentheses. ${ }^{* * *} p<0.01,{ }^{* *} p<0.05,{ }^{*} p<0.1$. 
Table A.2: Lagged effect of cumulative ESIF on the readmission rate - full model

\begin{tabular}{|c|c|c|c|c|}
\hline & $\begin{array}{c}(1) \\
\text { Readmission } \\
\text { rate } 30 \text { days }\end{array}$ & $\begin{array}{c}(2) \\
\text { Readmission } \\
\text { rate } 30 \text { days }\end{array}$ & $\begin{array}{c}(3) \\
\text { Readmission } \\
\text { rate } 30 \text { days }\end{array}$ & $\begin{array}{c}(4) \\
\text { Readmission } \\
\text { rate } 30 \text { days }\end{array}$ \\
\hline Constant & $\begin{array}{l}-0.785390 \\
(0.626623)\end{array}$ & $\begin{array}{l}-0.792601 \\
(0.629372)\end{array}$ & $\begin{array}{c}1.154970 \\
(0.852947)\end{array}$ & $\begin{array}{c}1.178965 \\
(0.842379)\end{array}$ \\
\hline Lag_ ESIF & $\begin{array}{l}-0.000463 \\
(0.000287)\end{array}$ & & $\begin{array}{c}-0.000757^{* * *} \\
(0.000272)\end{array}$ & \\
\hline Lag_construction & & $\begin{array}{c}-0.000775^{* * *} \\
(0.000192)\end{array}$ & & $\begin{array}{c}-0.000906^{* * *} \\
(0.000237)\end{array}$ \\
\hline Lag_equipment & & $\begin{array}{c}0.000652^{* * *} \\
(0.000239)\end{array}$ & & $\begin{array}{c}0.000740^{* * *} \\
(0.000250)\end{array}$ \\
\hline Lag_persother & & $\begin{array}{l}-0.000407 \\
(0.000370)\end{array}$ & & $\begin{array}{c}-0.000771^{* *} \\
(0.000324)\end{array}$ \\
\hline Capacity & $\begin{array}{c}0.000052 \\
(0.000312)\end{array}$ & $\begin{array}{c}0.000091 \\
(0.000297)\end{array}$ & $\begin{array}{c}0.000427 \\
(0.000334)\end{array}$ & $\begin{array}{c}0.000459 \\
(0.000314)\end{array}$ \\
\hline Occupancy & $\begin{array}{c}0.050533 \\
(0.039044)\end{array}$ & $\begin{array}{c}0.042946 \\
(0.039733)\end{array}$ & $\begin{array}{c}0.025954 \\
(0.033427)\end{array}$ & $\begin{array}{c}0.015898 \\
(0.032614)\end{array}$ \\
\hline New patients & $\begin{array}{c}-0.021922^{* * *} \\
(0.007937)\end{array}$ & $\begin{array}{c}-0.022567 * * * \\
(0.007844)\end{array}$ & $\begin{array}{l}-0.013669^{*} \\
(0.008074)\end{array}$ & $\begin{array}{l}-0.014256^{*} \\
(0.008105)\end{array}$ \\
\hline Medical devices & $\begin{array}{c}0.004876 \\
(0.011617)\end{array}$ & $\begin{array}{c}0.003975 \\
(0.011693)\end{array}$ & $\begin{array}{c}0.000499 \\
(0.010795)\end{array}$ & $\begin{array}{l}-0.000901 \\
(0.010615)\end{array}$ \\
\hline IC & $\begin{array}{l}-0.000544 \\
(0.005786)\end{array}$ & $\begin{array}{l}-0.000401 \\
(0.005946)\end{array}$ & $\begin{array}{l}-0.007310 \\
(0.004887)\end{array}$ & $\begin{array}{l}-0.007221 \\
(0.005034)\end{array}$ \\
\hline Oncology & $\begin{array}{c}0.007604 \\
(0.009528)\end{array}$ & $\begin{array}{c}0.008716 \\
(0.009006)\end{array}$ & $\begin{array}{l}-0.002632 \\
(0.006267)\end{array}$ & $\begin{array}{l}-0.000670 \\
(0.005412)\end{array}$ \\
\hline $\mathrm{CT}$ & $\begin{array}{l}-0.001968 \\
(0.003111)\end{array}$ & $\begin{array}{l}-0.001622 \\
(0.003101)\end{array}$ & $\begin{array}{l}-0.000822 \\
(0.002922)\end{array}$ & $\begin{array}{l}-0.000425 \\
(0.002855)\end{array}$ \\
\hline MR & $\begin{array}{l}-0.006329 \\
(0.003889)\end{array}$ & $\begin{array}{l}-0.005996 \\
(0.003829)\end{array}$ & $\begin{array}{c}-0.005077^{* *} \\
(0.002339)\end{array}$ & $\begin{array}{c}-0.004690^{* *} \\
(0.002260)\end{array}$ \\
\hline State hospital & $\begin{array}{c}-0.011444^{* * *} \\
(0.003733)\end{array}$ & $\begin{array}{c}-0.011232^{* * *} \\
(0.003830)\end{array}$ & $\begin{array}{c}-0.016106^{* * *} \\
(0.002924)\end{array}$ & $\begin{array}{c}-0.015946^{* * *} \\
(0.002899)\end{array}$ \\
\hline Regional hospital & $\begin{array}{l}-0.004278 \\
(0.003745)\end{array}$ & $\begin{array}{l}-0.004157 \\
(0.003809)\end{array}$ & $\begin{array}{c}0.000508 \\
(0.003117)\end{array}$ & $\begin{array}{c}0.000717 \\
(0.003150)\end{array}$ \\
\hline Perinatal mortality & $\begin{array}{c}0.001440 \\
(0.001615)\end{array}$ & $\begin{array}{c}0.001366 \\
(0.001652)\end{array}$ & $\begin{array}{c}0.000229 \\
(0.001431)\end{array}$ & $\begin{array}{c}0.000119 \\
(0.001443)\end{array}$ \\
\hline Average wage & $\begin{array}{c}0.029405 \\
(0.028528)\end{array}$ & $\begin{array}{c}0.033204 \\
(0.028508)\end{array}$ & $\begin{array}{c}0.004548 \\
(0.027010)\end{array}$ & $\begin{array}{c}0.008963 \\
(0.026846)\end{array}$ \\
\hline Roma share & $\begin{array}{l}-0.056345 \\
(0.037615)\end{array}$ & $\begin{array}{l}-0.054630 \\
(0.037073)\end{array}$ & $\begin{array}{l}-0.047380 \\
(0.029981)\end{array}$ & $\begin{array}{l}-0.045273 \\
(0.028874)\end{array}$ \\
\hline Econ dependency & $\begin{array}{c}0.083215^{* *} \\
(0.040359)\end{array}$ & $\begin{array}{c}0.080566^{* *} \\
(0.040026)\end{array}$ & $\begin{array}{l}-0.015373 \\
(0.035883)\end{array}$ & $\begin{array}{l}-0.019533 \\
(0.034995)\end{array}$ \\
\hline Population density & $\begin{array}{c}0.077464 \\
(0.128693)\end{array}$ & $\begin{array}{c}0.076632 \\
(0.129861)\end{array}$ & $\begin{array}{l}-0.209844 \\
(0.156662)\end{array}$ & $\begin{array}{l}-0.216376 \\
(0.155700)\end{array}$ \\
\hline Observations & 279 & 279 & 279 & 279 \\
\hline Individual FEs & Yes & Yes & Yes & Yes \\
\hline Time FEs & No & No & Yes & Yes \\
\hline $\mathrm{R}$-squared & 0.3214 & 0.3322 & 0.4365 & 0.4497 \\
\hline Adjusted R-squared & 0.279996 & 0.285952 & 0.392766 & 0.402433 \\
\hline F statistics & $4.11 * * *$ & $5.45 * * *$ & $16.42 * * *$ & $13.96 * * *$ \\
\hline
\end{tabular}

Notes: Robust standard errors in parentheses. ${ }^{* * *} p<0.01,{ }^{* *} p<0.05,{ }^{*} p<0.1$. 
Table A.3: Contemporaneous and lagged effect of cumulative ESIF on the mortality rate - full model

\begin{tabular}{|c|c|c|c|c|}
\hline & $\begin{array}{c}\text { (1) } \\
\text { Mortality rate }\end{array}$ & $\begin{array}{c}(2) \\
\text { Mortality rate }\end{array}$ & $\begin{array}{c}(3) \\
\text { Mortality rate }\end{array}$ & $\begin{array}{c}\text { (4) } \\
\text { Mortality rate }\end{array}$ \\
\hline Constant & $\begin{array}{l}-0.0164 \\
(0.0263)\end{array}$ & $\begin{array}{l}-0.0167 \\
(0.0262)\end{array}$ & $\begin{array}{c}0.2276 \\
(0.1441)\end{array}$ & $\begin{array}{c}0.2346 \\
(0.1469)\end{array}$ \\
\hline ESIF & $\begin{array}{c}0.0000 \\
(0.0001)\end{array}$ & & & \\
\hline Lag_ESIF & & & $\begin{array}{c}0.0000 \\
(0.0001)\end{array}$ & \\
\hline Construction & & $\begin{array}{l}-0.0000 \\
(0.0001)\end{array}$ & & \\
\hline Equipment & & $\begin{array}{c}0.0000 \\
(0.0001)\end{array}$ & & \\
\hline Persother & & $\begin{array}{c}0.0001 \\
(0.0001)\end{array}$ & & \\
\hline Lag_construction & & & & $\begin{array}{c}0.0000 \\
(0.0001)\end{array}$ \\
\hline Lag_equipment & & & & $\begin{array}{c}0.0000 \\
(0.0001)\end{array}$ \\
\hline Lag_persother & & & & $\begin{array}{l}-0.0001 \\
(0.0001)\end{array}$ \\
\hline Capacity & $\begin{array}{c}0.0000 \\
(0.0001)\end{array}$ & $\begin{array}{c}0.0000 \\
(0.0001)\end{array}$ & $\begin{array}{l}-0.0000 \\
(0.0001)\end{array}$ & $\begin{array}{c}-0.0000 \\
(0.0001)\end{array}$ \\
\hline Occupancy & $\begin{array}{c}0.0015 \\
(0.0078)\end{array}$ & $\begin{array}{c}0.0014 \\
(0.0078)\end{array}$ & $\begin{array}{c}-0.0102^{*} \\
(0.0055)\end{array}$ & $\begin{array}{c}-0.0106^{*} \\
(0.0057)\end{array}$ \\
\hline New patients & $\begin{array}{l}-0.0020 \\
(0.0017)\end{array}$ & $\begin{array}{l}-0.0020 \\
(0.0017)\end{array}$ & $\begin{array}{c}-0.0032^{* *} * \\
(0.0014)\end{array}$ & $\begin{array}{c}-0.0031 * * \\
(0.0014)\end{array}$ \\
\hline Medical devices & $\begin{array}{l}-0.0004 \\
(0.0030)\end{array}$ & $\begin{array}{l}-0.0003 \\
(0.0030)\end{array}$ & $\begin{array}{l}-0.0020 \\
(0.0036)\end{array}$ & $\begin{array}{l}-0.0022 \\
(0.0037)\end{array}$ \\
\hline $\mathrm{IC}$ & $\begin{array}{l}-0.0004 \\
(0.0015)\end{array}$ & $\begin{array}{l}-0.0003 \\
(0.0016)\end{array}$ & $\begin{array}{l}-0.0011 \\
(0.0015)\end{array}$ & $\begin{array}{l}-0.0011 \\
(0.0015)\end{array}$ \\
\hline Oncology & $\begin{array}{c}0.0002 \\
(0.0007)\end{array}$ & $\begin{array}{c}0.0002 \\
(0.0007)\end{array}$ & $\begin{array}{l}-0.0003 \\
(0.0009)\end{array}$ & $\begin{array}{c}0.0000 \\
(0.0007)\end{array}$ \\
\hline $\mathrm{CT}$ & $\begin{array}{c}0.0005 \\
(0.0009)\end{array}$ & $\begin{array}{c}0.0005 \\
(0.0009)\end{array}$ & $\begin{array}{c}0.0011 \\
(0.0009)\end{array}$ & $\begin{array}{c}0.0011 \\
(0.0009)\end{array}$ \\
\hline MR & $\begin{array}{c}0.0001 \\
(0.0005)\end{array}$ & $\begin{array}{c}0.0001 \\
(0.0005)\end{array}$ & $\begin{array}{c}0.0005 \\
(0.0005)\end{array}$ & $\begin{array}{c}0.0006 \\
(0.0005)\end{array}$ \\
\hline State hospital & $\begin{array}{c}-0.0025^{* *} \\
(0.0011)\end{array}$ & $\begin{array}{c}-0.0025^{* *} \\
(0.0011)\end{array}$ & $\begin{array}{c}-0.0026^{* *} \\
(0.0012)\end{array}$ & $\begin{array}{c}-0.0026 * * \\
(0.0012)\end{array}$ \\
\hline Regional hospital & $\begin{array}{l}-0.0008 \\
(0.0007)\end{array}$ & $\begin{array}{l}-0.0009 \\
(0.0007)\end{array}$ & $\begin{array}{l}-0.0006 \\
(0.0007)\end{array}$ & $\begin{array}{l}-0.0006 \\
(0.0007)\end{array}$ \\
\hline Perinatal mortality & $\begin{array}{l}-0.0001 \\
(0.0003)\end{array}$ & $\begin{array}{l}-0.0002 \\
(0.0003)\end{array}$ & $\begin{array}{l}-0.0003 \\
(0.0003)\end{array}$ & $\begin{array}{l}-0.0003 \\
(0.0003)\end{array}$ \\
\hline Average wage & $\begin{array}{l}-0.0025 \\
(0.0024)\end{array}$ & $\begin{array}{l}-0.0026 \\
(0.0025)\end{array}$ & $\begin{array}{l}-0.0035 \\
(0.0032)\end{array}$ & $\begin{array}{l}-0.0035 \\
(0.0032)\end{array}$ \\
\hline Roma share & $\begin{array}{l}0.0029^{*} \\
(0.0016)\end{array}$ & $\begin{array}{l}0.0030^{*} \\
(0.0016)\end{array}$ & $\begin{array}{c}0.0027 \\
(0.0067)\end{array}$ & $\begin{array}{c}0.0020 \\
(0.0069)\end{array}$ \\
\hline Econ dependency & $\begin{array}{c}0.0039 \\
(0.0024)\end{array}$ & $\begin{array}{c}0.0037 \\
(0.0024)\end{array}$ & $\begin{array}{c}0.0038 \\
(0.0024)\end{array}$ & $\begin{array}{c}0.0037 \\
(0.0024)\end{array}$ \\
\hline Population density & $\begin{array}{c}0.0102^{* *} \\
(0.0047)\end{array}$ & $\begin{array}{c}0.0105 * * \\
(0.0048)\end{array}$ & $\begin{array}{l}-0.0335 \\
(0.0298)\end{array}$ & $\begin{array}{l}-0.0349 \\
(0.0305)\end{array}$ \\
\hline Observations & 344 & 344 & 289 & 289 \\
\hline Individual FEs & Yes & Yes & Yes & Yes \\
\hline R-squared & 0.0851 & 0.0880 & 0.1352 & 0.1384 \\
\hline Adjusted R-squared & 0.0403 & 0.0376 & 0.0843 & 0.0809 \\
\hline F statistics & $1.93^{* *}$ & 1.51 & $2.39 * * *$ & $2.17^{* *}$ \\
\hline
\end{tabular}

Notes: Robust standard errors in parentheses. ${ }^{* * *} p<0.01,{ }^{* *} p<0.05,{ }^{*} p<0.1$. Regressions with time-fixed effects did not differ significantly from those with individual fixed effects. 
Table A.4: Contemporaneous effect of cumulative ESIF on the mortality rate in selected categories - full model (part 1)

\begin{tabular}{|c|c|c|c|c|}
\hline & $\begin{array}{c}(1) \\
\text { Mortality after } \\
\text { femur fracture } \\
\text { (age over 65) }\end{array}$ & $\begin{array}{c}(2) \\
\text { Mortality caused } \\
\text { by myocardial } \\
\text { infarction after } \\
\text { emergency } \\
\text { (age 35-74) }\end{array}$ & $\begin{array}{c}\text { (3) } \\
\text { Mortality after } \\
\text { acute stroke }\end{array}$ & $\begin{array}{c}(4) \\
\text { Mortality after } \\
\text { interventions }\end{array}$ \\
\hline Constant & $\begin{array}{c}-1.4762^{*} \\
(0.8261)\end{array}$ & $\begin{array}{c}0.0512 \\
(0.8355)\end{array}$ & $\begin{array}{c}2.3563 \\
(1.4376)\end{array}$ & $\begin{array}{c}0.0355 \\
(0.1353)\end{array}$ \\
\hline ESIF & $\begin{array}{l}0.0027^{*} \\
(0.0014)\end{array}$ & $\begin{array}{c}0.0028^{* *} \\
(0.0012)\end{array}$ & $\begin{array}{c}0.0015 \\
(0.0022)\end{array}$ & $\begin{array}{l}-0.0001 \\
(0.0002)\end{array}$ \\
\hline Capacity & $\begin{array}{l}-0.0006 \\
(0.0010)\end{array}$ & $\begin{array}{c}-0.0036^{* *} \\
(0.0015)\end{array}$ & $\begin{array}{l}-0.0028 \\
(0.0033)\end{array}$ & $\begin{array}{l}0.0005^{*} \\
(0.0002)\end{array}$ \\
\hline Occupancy & $\begin{array}{c}-0.1777 \\
(0.2148)\end{array}$ & $\begin{array}{c}0.0600 \\
(0.1696)\end{array}$ & $\begin{array}{c}0.2163 \\
(0.2471)\end{array}$ & $\begin{array}{c}0.0412 \\
(0.0274)\end{array}$ \\
\hline New patients & $\begin{array}{c}0.0385 \\
(0.0486)\end{array}$ & $\begin{array}{c}0.0403 \\
(0.0508)\end{array}$ & $\begin{array}{l}-0.0690 \\
(0.0934)\end{array}$ & $\begin{array}{c}-0.0019 \\
(0.0062)\end{array}$ \\
\hline Medical devices & $\begin{array}{l}-0.0143 \\
(0.0479)\end{array}$ & $\begin{array}{l}-0.0379 \\
(0.0592)\end{array}$ & $\begin{array}{c}0.0016 \\
(0.0819)\end{array}$ & $\begin{array}{c}0.0014 \\
(0.0089)\end{array}$ \\
\hline IC & $\begin{array}{l}-0.0016 \\
(0.0356)\end{array}$ & $\begin{array}{c}0.0355 \\
(0.0477)\end{array}$ & $\begin{array}{c}-0.0359 * * \\
(0.0145)\end{array}$ & $\begin{array}{c}0.0034 \\
(0.0045)\end{array}$ \\
\hline Oncology & $\begin{array}{c}0.0306^{* *} \\
(0.0138)\end{array}$ & $\begin{array}{c}0.0522^{* * *} \\
(0.0190)\end{array}$ & $\begin{array}{c}0.0138 \\
(0.0270)\end{array}$ & $\begin{array}{c}-0.0041^{*} \\
(0.0022)\end{array}$ \\
\hline $\mathrm{CT}$ & $\begin{array}{c}-0.0218 \\
(0.0164)\end{array}$ & $\begin{array}{c}0.0255^{*} \\
(0.0139)\end{array}$ & $\begin{array}{l}-0.0125 \\
(0.0095)\end{array}$ & $\begin{array}{l}0.0037^{*} \\
(0.0021)\end{array}$ \\
\hline MR & $\begin{array}{l}-0.0044 \\
(0.0084)\end{array}$ & $\begin{array}{c}0.0310^{* *} \\
(0.0147)\end{array}$ & $\begin{array}{c}-0.0246^{*} \\
(0.0128)\end{array}$ & $\begin{array}{c}0.0008 \\
(0.0018)\end{array}$ \\
\hline State hospital & $\begin{array}{c}-0.1664^{* * * *} \\
(0.0431)\end{array}$ & $\begin{array}{c}0.0049 \\
(0.0329)\end{array}$ & $\begin{array}{c}-0.1163^{* *} \\
(0.0447)\end{array}$ & $\begin{array}{c}0.0163 * * * \\
(0.0048)\end{array}$ \\
\hline Regional hospital & $\begin{array}{c}0.0048 \\
(0.0183)\end{array}$ & $\begin{array}{c}0.0072 \\
(0.0158)\end{array}$ & $\begin{array}{l}-0.1025 \\
(0.0774)\end{array}$ & $\begin{array}{c}0.0001 \\
(0.0033)\end{array}$ \\
\hline Perinatal mortality & $\begin{array}{c}-0.0092 \\
(0.0088)\end{array}$ & $\begin{array}{l}-0.0040 \\
(0.0104)\end{array}$ & $\begin{array}{c}0.0075 \\
(0.0070)\end{array}$ & $\begin{array}{l}-0.0001 \\
(0.0017)\end{array}$ \\
\hline Average wage & $\begin{array}{c}-0.0798 \\
(0.0885)\end{array}$ & $\begin{array}{c}-0.2210^{* *} \\
(0.0882)\end{array}$ & $\begin{array}{c}0.0081 \\
(0.0929)\end{array}$ & $\begin{array}{c}0.0025 \\
(0.0158)\end{array}$ \\
\hline Roma share & $\begin{array}{c}0.0374 \\
(0.0292)\end{array}$ & $\begin{array}{c}-0.0368 \\
(0.0249)\end{array}$ & $\begin{array}{l}-0.0125 \\
(0.0243)\end{array}$ & $\begin{array}{l}-0.0036 \\
(0.0036)\end{array}$ \\
\hline Econ dependency & $\begin{array}{c}-0.0027 \\
(0.0941)\end{array}$ & $\begin{array}{c}-0.0051 \\
(0.0809)\end{array}$ & $\begin{array}{c}-0.1712^{*} \\
(0.0983)\end{array}$ & $\begin{array}{c}0.0174 \\
(0.0110)\end{array}$ \\
\hline Population density & $\begin{array}{c}0.4375^{* * *} \\
(0.1611)\end{array}$ & $\begin{array}{c}0.2483 \\
(0.1558)\end{array}$ & $\begin{array}{c}-0.2909 \\
(0.2536)\end{array}$ & $\begin{array}{l}-0.0217 \\
(0.0203)\end{array}$ \\
\hline Observations & 271 & 282 & 306 & 319 \\
\hline Individual FEs & Yes & Yes & Yes & Yes \\
\hline R-squared & 0.1142 & 0.0974 & 0.0781 & 0.1212 \\
\hline Adjusted R-squared & 0.0585 & 0.0429 & 0.0271 & 0.0747 \\
\hline F statistics & $441.71^{* * *}$ & $4.19^{* * *}$ & $22.90 * * *$ & $335.94^{* * *}$ \\
\hline
\end{tabular}

Notes: Robust standard errors in parentheses. ${ }^{* * *} p<0.01,{ }^{* *} p<0.05,{ }^{*} p<0.1$. 
Table A.5: Contemporaneous effect of cumulative ESIF on the mortality rate in selected categories - full model (part 2)

\begin{tabular}{|c|c|c|c|c|c|}
\hline & $\begin{array}{l}(5) \\
\text { Mortality in } \\
\text { ICUs }\end{array}$ & $\begin{array}{l}\text { (6) } \\
\text { Ratio of trans- } \\
\text { fers to ICUs }\end{array}$ & $\begin{array}{l}(7) \\
\text { Mortality in } \\
\text { regular wards } \\
\text { after a trans- } \\
\text { fer from ICU }\end{array}$ & $\begin{array}{l}(8) \\
\text { Pressure } \\
\text { ulcer }\end{array}$ & $\begin{array}{l}(9) \\
\text { Operation } \\
\text { rate }\end{array}$ \\
\hline Constant & $\begin{array}{c}0.3189 \\
(0.1901)\end{array}$ & $\begin{array}{r}-5.3445^{*} \\
(2.9647)\end{array}$ & $\begin{array}{l}-0.0042 \\
(0.0085)\end{array}$ & $\begin{array}{c}0.0107 \\
(0.0091)\end{array}$ & $\begin{array}{l}-0.1128 \\
(2.7022)\end{array}$ \\
\hline ESIF & $\begin{array}{c}-0.0014^{* *} \\
(0.0005)\end{array}$ & $\begin{array}{l}-0.0072 \\
(0.0044)\end{array}$ & $\begin{array}{c}0.0000477^{*} \\
(0.0000259)\end{array}$ & $\begin{array}{c}0.0000 \\
(0.0000)\end{array}$ & $\begin{array}{l}-0.0043 \\
(0.0029)\end{array}$ \\
\hline Capacity & $\begin{array}{c}0.0010 \\
(0.0006)\end{array}$ & $\begin{array}{c}0.0009 \\
(0.0049)\end{array}$ & $\begin{array}{l}-0.0000 \\
(0.0000)\end{array}$ & $\begin{array}{l}-0.0000 \\
(0.0000)\end{array}$ & $\begin{array}{l}-0.0028 \\
(0.0025)\end{array}$ \\
\hline Occupancy & $\begin{array}{l}-0.0022 \\
(0.0275)\end{array}$ & $\begin{array}{c}0.0468 \\
(0.4603)\end{array}$ & $\begin{array}{l}-0.0039 \\
(0.0042)\end{array}$ & $\begin{array}{l}-0.0007 \\
(0.0028)\end{array}$ & $\begin{array}{l}-0.0237 \\
(0.2116)\end{array}$ \\
\hline New patients & $\begin{array}{c}0.0076 \\
(0.0133)\end{array}$ & $\begin{array}{l}-0.0163 \\
(0.1331)\end{array}$ & $\begin{array}{c}0.0003 \\
(0.0006)\end{array}$ & $\begin{array}{c}0.0004 \\
(0.0006)\end{array}$ & $\begin{array}{c}0.0896 \\
(0.0933)\end{array}$ \\
\hline Medical devices & $\begin{array}{c}0.0443^{* *} \\
(0.0200)\end{array}$ & $\begin{array}{c}-0.1093 \\
(0.1892)\end{array}$ & $\begin{array}{l}-0.0008 \\
(0.0018)\end{array}$ & $\begin{array}{l}-0.0002 \\
(0.0017)\end{array}$ & $\begin{array}{c}0.0162 \\
(0.1275)\end{array}$ \\
\hline $\mathrm{IC}$ & & & & $\begin{array}{l}-0.0003 \\
(0.0003)\end{array}$ & $\begin{array}{l}0.1389 * * \\
(0.0546)\end{array}$ \\
\hline Oncology & $\begin{array}{c}-0.0088 \\
(0.0065)\end{array}$ & $\begin{array}{c}0.0023 \\
(0.0428)\end{array}$ & $\begin{array}{l}-0.0001 \\
(0.0002)\end{array}$ & $\begin{array}{c}0.0001 \\
(0.0003)\end{array}$ & $\begin{array}{c}0.0667 \\
(0.0486)\end{array}$ \\
\hline $\mathrm{CT}$ & $\begin{array}{c}0.0055 \\
(0.0056)\end{array}$ & $\begin{array}{c}0.0214 \\
(0.0306)\end{array}$ & $\begin{array}{l}-0.0002 \\
(0.0002)\end{array}$ & $\begin{array}{l}-0.0005 \\
(0.0004)\end{array}$ & $\begin{array}{c}0.0103 \\
(0.0183)\end{array}$ \\
\hline MR & $\begin{array}{l}0.0059^{*} \\
(0.0030)\end{array}$ & $\begin{array}{l}-0.0004 \\
(0.0320)\end{array}$ & $\begin{array}{c}0.0000 \\
(0.0001)\end{array}$ & $\begin{array}{l}-0.0002 \\
(0.0003)\end{array}$ & $\begin{array}{l}-0.0395 \\
(0.0241)\end{array}$ \\
\hline State hospital & $\begin{array}{c}-0.0368 * * * \\
(0.0034)\end{array}$ & $\begin{array}{c}-0.1181^{* * *} \\
(0.0372)\end{array}$ & $\begin{array}{c}0.0008 \\
(0.0008)\end{array}$ & $\begin{array}{c}0.0007 \\
(0.0008)\end{array}$ & $\begin{array}{c}0.0022 \\
(0.0307)\end{array}$ \\
\hline Regional hospital & $\begin{array}{c}0.0039 \\
(0.0053)\end{array}$ & $\begin{array}{c}0.0402 \\
(0.0495)\end{array}$ & $\begin{array}{c}-0.0009 * * * \\
(0.0002)\end{array}$ & $\begin{array}{l}-0.0004 \\
(0.0003)\end{array}$ & $\begin{array}{c}-0.0678 * * \\
(0.0272)\end{array}$ \\
\hline Perinatal mortality & $\begin{array}{l}-0.0018 \\
(0.0021)\end{array}$ & $\begin{array}{c}0.0196 \\
(0.0186)\end{array}$ & $\begin{array}{c}0.0001 \\
(0.0001)\end{array}$ & $\begin{array}{c}0.0001 \\
(0.0001)\end{array}$ & $\begin{array}{c}0.0000 \\
(0.0135)\end{array}$ \\
\hline Average wage & $\begin{array}{l}-0.0470 \\
(0.0286)\end{array}$ & $\begin{array}{c}0.1083 \\
(0.2938)\end{array}$ & $\begin{array}{c}0.0004 \\
(0.0018)\end{array}$ & $\begin{array}{l}-0.0035^{*} \\
(0.0018)\end{array}$ & $\begin{array}{l}-0.1388 \\
(0.1133)\end{array}$ \\
\hline Roma share & $\begin{array}{c}0.0011 \\
(0.0068)\end{array}$ & $\begin{array}{c}0.0802 \\
(0.0660)\end{array}$ & $\begin{array}{l}-0.0012 \\
(0.0007)\end{array}$ & $\begin{array}{l}-0.0000 \\
(0.0004)\end{array}$ & $\begin{array}{c}0.1027^{* *} \\
(0.0432)\end{array}$ \\
\hline Econ dependency & $\begin{array}{c}0.0623 \\
(0.0519)\end{array}$ & $\begin{array}{c}1.5466^{* * *} \\
(0.4045)\end{array}$ & $\begin{array}{l}-0.0020 \\
(0.0034)\end{array}$ & $\begin{array}{c}0.0028 \\
(0.0017)\end{array}$ & $\begin{array}{l}0.2990^{* *} \\
(0.1409)\end{array}$ \\
\hline Population density & $\begin{array}{l}-0.0322 \\
(0.0231)\end{array}$ & $\begin{array}{c}0.0825 \\
(0.4155)\end{array}$ & $\begin{array}{c}0.0020 \\
(0.0012)\end{array}$ & $\begin{array}{c}0.0009 \\
(0.0017)\end{array}$ & $\begin{array}{c}0.0783 \\
(0.5028)\end{array}$ \\
\hline Observations & 220 & 220 & 221 & 339 & 291 \\
\hline Individual FEs & Yes & Yes & Yes & Yes & Yes \\
\hline R-squared & 0.1465 & 0.3663 & 0.1405 & 0.0541 & 0.1399 \\
\hline Adjusted R-squared & 0.0838 & 0.3198 & 0.0776 & 0.0072 & 0.0897 \\
\hline F statistics & $31.97 * * *$ & $41.83 * * *$ & $4.45 * * *$ & $1.91 * *$ & $5.23 * * *$ \\
\hline
\end{tabular}

Notes: Robust standard errors in parentheses. ${ }^{* * *} p<0.01,{ }^{* *} p<0.05,{ }^{*} p<0.1$. 